\title{
Comments
}

\section{JUDICIAL SUPERVISION OVER CALIFORNIA PLEA BARGAINING: REGULATING THE TRADE†}

Although plea bargaining has been legitimized as a means for bringing about convictions and setting the scope of sentencing alternatives, ${ }^{1}$ the state's role in pressuring defendants to plead guilty remains a matter of great concern. The California supreme court in a series of cases $^{2}$ has laid the groundwork for bringing this practice, which produces the overwhelming majority of convictions, ${ }^{3}$ under the supervision of the judiciary in order to promote fairness to the imdividual who pleads guilty.

This Comment exaunines the role of the judiciary in overseeing the quality of justice produced by a systein which has experienced unruly

$\dagger$ The empirical portions of this Comment, represented principally by part I, are derived from the author's study of the criminal process in Alameda and San Francisco Counties during the three months of spring 1970. Observation took place in both municipal and superior courts, but focus was upon cases originally charged as felonies. Interviews were had with judges, district attorneys, public defenders, private counsel, and San Quentin inmates. The author would particularly like to thank Judge Lionel Wilson, Superior Court, Alameda County; Mr. Michael Ciraolo, Deputy Public Defender, Alameda County; Mr. Walter Guibinni, Chief Assistant District Attomey, San Francisco County; and Mr. Cecil Poole, former United States Attomey for the Northern District of California and Regent's Professor of Law at the University of California at Berkeley, among the many persons who cooperated with the study.

1. Brady v. United States, 397 U.S. 742 (1970); People v. West, 3 Cal. 3d 595, 477 P.2d 409, 91 Cal. Rptr. 385 (1970).

2. In re Tahl, 1 Cal. 3d 122, 460 P.2d 449, 81 Cal. Rptr. 577 (1969) (Mosk, J.) (5-2 decision); In re Williams, 1 Cal. 3d 168, 460 P.2d 984, 81 Cal. Rptr. 784 (1969) ('Tobriner, J.) (unanimous decision); People v. Tenorio, 3 Cal. 3d 89, 473 P.2d 993, 89 Cal. Rptr. 249 (1970) (Peters, J.) (unammous decision); People v. West, 3 Cal. 3d 595, 477 P.2d 409, 91 Cal. Rptr. 385 (1970) (Tobriner, J.) (unanimous decision).

3. See In re Tahl, 1 Cal. 3d 122, 138, 460 P.2d 449, 461, 81 Cal. Rptr. 577, 589 (1969) (Peters, J., concurring and dissenting). Although statistics that show the use of plea bargaining up and down the state are not available, Justice Peters' assertion that plea bargaims are the rule not the exception is undoubtedly correct. The overwhelming majority of convictions are obtained short of trial. In 1968, for example, $59.5 \%$ of all felony defendants in California superior courts pleaded guilty. Another $17.6 \%$ waived jury trial, submitted the transcripts of their preliminary hearings, and wcre found guilty -an alternative form for processing a bargamed disposition in California. See text accompanying notes 73-77 infra. Another $8.5 \%$ were convicted at jury or court trials. The remaining $14.4 \%$ of the cases resulted in dismissal, acquittal, or suspension of prosecution for various reasons. Thus, $90 \%$ of all felony convictions were obtained short of trial through the acquiescence of defendants. CaL. Bureau of Criminal Statistics, Crime and Delinguency in California 15 (1968). 
and largely unguided growth. Part I focuses on the factors that make plea bargaining the principal form of criminal practice in California. Part II reviews the legal background of the guilty plea, the principles that arose in response to the unkept plea bargain, and the doctrine that insulates the guilty plea from attack on appeal. Part III discusses the rules that have been fashioned recently in hopes of insuring that a person will not forego trial because ignorant of his rights. Part IV analyzes the right to adequate counsel in the context of plea bargaining. Part $\mathrm{V}$ exarnines the threat to judicial power that plea bargaining poses and the role the courts must play in individualizing justice to reassert their governmental function.

\section{BARgaining Roles and Resulting STResses}

One practitioner has characterized plea bargaining as "guilt by rap sheet, trial by trick and deceit." Some observers prefer to point out the benefits that accrue to the state in obtaining convictions while saving time and resources, in terms of money and personnel, and defendants in receiving correctional dispositions that they help to design. ${ }^{5}$ Until recently it was argued that the process was unconstitutional in that its central feature, the assurance of leniency, placed an inpermissible burden on the exercise of the right to jury trial. ${ }^{6}$ Whatever the characterization, maneuvering for bargaining leverage in quest of dispositions short of trial has become the primary effort of the criminal bar in California." Examining the factors that make this so is important

4. A public defender interviewed by the author.

5. See, e.g., ABA Project on Minmum Standards for Criminat Justice, Standards Relating to Pleas of Gullty 2-3 (tent. draft 1967), adopted as amended, 2 CRMM. L. Rep. 2422 (1968) [hereinafter cited as ABA StaNdards Relating to Pleas of Guilty].

6. See, e.g., Note, The Unconstitutionality of Plea Bargaining, 83 HARv. L. REv. 1387 (1970).

7. Defense attorney Stan Golde's remarks in Cal. Contrnutng Education of the Bar, Californta Crimmal Law Practice 132 (1964) are illuminating:

It is your duty as an attorney to communicate with the district attorney's office to attempt to arrive at some fair and just disposition of the case slort of a jury trial. It is certainly proper to ask the deputy district attorney about the type of case lie lias. You may ask what information he lias, whiat the facts show, and whether lie feels he has a good charge. You will find that the district attorney is usually interested in seeing that justice is done, and that lie also is inclined to dispose of the case in some manner short of a jury trial. But you must be honest with yourself as well as with the district attorney. It will do your client little good to ask for some unreasonable disposition of the case. A courteous and realistic attitude toward the district attorney can result in great benefit for your client.

The district attorney has authority to dismiss the case or to accept a plea to a lesser charge. He can make a recommendation on sentence that is usually followed by the court. He can also inform the court that the defendant is co- 
in evaluating the systein and in formulating a principled response to it. $^{8}$

The district attorney's foremost bargaining tool is his use of his charging function to pose the threat of heavy punishment. His decision as to the nature and number of charges to be pressed is not subject to effective judicial check in the great majority of cases;" and the California Penal Code, which has been described as "notorious for its repetitive and overlapping provisions" providing for "senseless multiplication of punishment,"10 is admirably suited to the strategy of threatening heavy punishment. Moreover, California's system of indeterminate sentencing greatly reinforces the district attorney's bargaining hand. Conviction for a felony, if followed by commitment to state prison, turns the person over to the California Adult Authority, an administrative agency, for release at its discretion within a maximum term ${ }^{11}$ which is set quite heavily under many sections of the Penal Code. ${ }^{12}$ Pleading guilty to a misdemeanor, on the other hand, assures commitment in the county jail-

operating with the authorities, a factor that the court will take into considera-

tion in sentencing.

8. For studies of factors that influence bargaining in other jurisdictions, see D. Newman, Conviction: The Determination of Guint oR InNocence Without TrIal (1966); Ahschuler, The Prosecutor's Role in Plea Bargaining, 36 U. CHI. L. REv. 50 (1968).

9. Ideally the preliminary hearing might operate as a screening device in felony cases, but magistrates seein to find probable cause for prosecution routinely at preliminary hearings. The evidentiary value of the case has not been tested in the past short of trial, a stage that most cases do not reach. Heavy or improper charging with a view towards influencing the defendant to convict himself is a reported and observable phenomenon. See Comment, Prosecutorial Discretion in the Initiation of Criminal Complaints, 42 S. CAL. L. REv. 519, 532 (1969). One-fourth of the deputy district attorneys surveyed knew of instances where charges more serious than the evidence warranted had been filed to influence plea decisions. Another one-fourth said they knew of complaints filed in order to "cover" for the police. See McDonald v. Musick, 425 F.2d 373 (9th Cir. 1970) (increased charges pressed for defendant's unwillingness to stipulate to probable cause for arrest as condition for dismissal of his case); cf. In re Willians, 1 Cal. 3d 168, 178, 460 P.2d 984, 991, 81 Cal. Rptr. 784, 791 (1969); People v. Aseltine, 139 Cal. App. 768, 770, 34 P.2d 830, 831-32 (2d Dist. 1934).

10. Johnson, Multiple Punishment and Consecutive Sentences, 58 CaLIf. L. Rev. 357, 360 (1970). Many defendants have committed petty economic crimes, e.g., bad check passing, credit card offenses, theft, or crimes without victims, e.g., marijuana possession, prostitution. See District ATtorney, S.F. COUNTY, ANNUAL REPORT To THE MAYOR 1968-1969, at 4, 6 (1969) [heremafter cited as ANNUAL ReporT]. The Penal Code prescribes heavy punishment for many of these offenses. Forgery of a credit card voucher, for exainple, no matter for what ainount, is punishable by 1-14 years in the state prison. Cal. Penal. Code $\$ 484 \mathrm{f}$ (West 1970).

11. Cal. Penal Code $\$ 5077$ (West 1970). For a discussion of the Adult Authority and California's system of indeterminate sentencing, see Johnson, supra note 10, at 379-89.

12. E.g., CaI. Penal Code $\$ 213$ (West 1970) (first degree robbery, 5 years-life); $i d$. $\$ 213$ (second degree robbery, 1 year-life); id. \$ 264 (rape, 1-50 years); $i d$. $\$ 288 a$ (oral copulation, 1-15 years); id. $\$ 473$ (forgery, 1-14 years). 
away from the jurisdiction of the Adult Authority-for no more than one year. ${ }^{13}$ A person who, failing to raise bail, has already spent months in the jail, perhaps under extraordinarily bad conditions, ${ }^{14}$ is likely to be strongly influenced by the possibility of probation or a short sentence with credit for time served, as opposed to the risk, however slight, of being convicted and sentenced more heavily.

The majority of defendants convict themselves in response to express or implied promises of leniency made ordinarily by the prosecutor, defense counsel, or the judge who presides over the pre-trial criminal calendar $^{16}$ or the trial court. ${ }^{16}$ The real benefit received from plea bargains varies widely among defendants. A person who convicts himself, particularly of a felony, may not receive the benefit he was led to expect. It is known but rarely expressed clearly to defendants that the Adult Authority weighs all the charges that were brought in the subject prosecution, as well as any prior arrests or convictions, in deciding when to release a pris-

13. Id. $\S 19$ a. During 1968-1969 in San Francisco County, felony charges were brought against 8,058 persons. Of these $29.8 \%$ pleaded guilty to misdemeanors at or before the time scheduled for preliminary hearing. Twenty-three persons (.3\%) pleaded guilty to a felony. Forty percent were held to answer in superior court. Another $17.5 \%$ of the cases were dismissed, while $6.2 \%$ went straight to superior court by way of indictment. The remaining $6.2 \%$ had been referred to juvenile court or were pending at the close of the reporting period. See ANNUAL REPORT 4.

14. The "Greystone" section of Santa Rita Prison Farm in Alameda County is particularly notorious and has been under personal investigation by Federal District Judge Alfonso J. Zirpoli in connection with a class action law suit brought by the Alameda County Legal Aid Society. Iudge Zirpoli has termed the facility "barbaric," "cruel and unusual punishment for man or beast." "[Even more shocking is that many of those confined there] are persons who are awaiting trial, have yet to be found guilty, and are presumed under law to be innocent of wrongdoing." S.F. Chromicle, Mar. 12, 1971, at 1, col. 1. Persons awaiting trial are not allowed the exercise and recreation afforded convicted inmates. Id., Feb. 26, 1971, at 22, col. 1. Every Alameda County defense attorney interviewed by the author believed that defendants were kept under these conditions in order to influence plea decisions. Fully one-half of all prisoners incarcerated in California county jails on any given day have not yet been couvicted of crime. See Office of Research, CaI. Assembly, Prelimmart Report on the Costs and Effects of the Califorma Criminal Iustice System and RecommendatToNs For Legislation to Increase Support of local police and Corrective PROGRAMS 144 (1969).

15. In the superior courts of both Alameda and San Francisco Counties, all felony cases awaiting trial are routed through the judge who presides over the criminal calendar for arraignment on the fornal charges by way of information or indictment, to be followed by disposition short of trial or assignment for trial. Approximately onethird of felony cases do not reach superior court because they are dealt out as misdeineanors at the mumicipal court level sometime after arraignment on the felony complaint. See note 13 supra.

16. It should be apparent that the usual appellation of "trial court" or "trial judge" in reference to the non-appellate judiciary is not descriptive of the pre-trial dispositional function which accounts for the processing of most criminal cases, although some guilty pleas are taken after a jury has been impaneled. Throughout this Comment, the author observes the usual practice instead of adopting the more appropriate but somewhat inelegant title of "pre-trial judge." 
oner. ${ }^{17}$ Thus, a person can serve time in effect for the charges which were dismissed pursuant to the bargain - the Adult Authority inerely holds him beyond the median time served by persons convicted of the charge to which he pleaded guilty. After the prisoner is paroled the Authority can revoke his parole and refix the sentence at the maximum ${ }^{18}$ for almost any reason so long as it does not act arbitrarily. ${ }^{18}$ Revoeation is often made on the basis of a subsequent arrest that does not result $\mathrm{m}$ conviction $^{20}$ or the breaking of strict disciplinary rules which the Authority attaches to parole. ${ }^{21}$ Thus any felony commitment can become a treadmill.

A grant of felony probation can also be a benefit which may prove to be largely illusory. For most felony offenses the Penal Code permits the sentencing judge to suspend execution of the sentence and impose probation conditioned on serving some time, up to one year, im the county jail. ${ }^{22}$ This type of judgment has the initial impact of only a misdemeanor, but the court may revoke probation on any reasonable grounds, ${ }^{28}$ which, as in parole revocation, may mclude the breaking of disciplinary rules or a subsequent arrest not followed by conviction. Once a person's probation is revoked he cannot be released by a judicial officer even though all the charges that formed the basis for revocation are dismissed later. ${ }^{24}$

17. See the remarks of two justices of the California supreme court: In re Tahl, 1 Cal. 3d 122, 139, 460 P.2d 449, 461, 81 Cal. Rptr. 577, 589 (1969) (Peters, J., dissenting); Justice Burke, speech at the 1970 Sentencing Institute for Superior Court Judges, reported in 93 Cal. Rptr. app. 14, 22.

18. Cal. Penal Code $\S \S 5077,5078$ (West 1970). The Adult Authority has the power under these sections to fix, within the maximum, the term that a convicted person will serve. If parole is revoked before the term has expired, the Authority can refix the sentence up to the maximum. See In re McLaim, 55 Cal. 2d 78, 357 P.2d 1080, 9 Cal. Rptr. 824 (1969); In re Brown, 67 Cal. 2d 339, 431 P.2d 630, 632, 62 Cal. Rptr. 6, 8 (1967).

19. In re Marks, 71 Cal. 2d 31, 46, 453 P.2d 441, 451, 77 Cal. Rptr. 1, 11 (1969); Pope v. Superior Court, 9 Cal. App. 3d 636, 641, 88 Cal. Rptr. 488, 490 (1st Dist. 1970).

20. If the subsequent prosecution results in acquittal and nothing else supports the revocation, it is assumed that the parole will be reinstated. Ex parte Payton, 28 Cal. 2d 194, 197, 169 P.2d 361, 363 (1946). But a revocation based on "parole behavior" is sustainable even though it is not based on a vahid conviction. See In re Martinez, 1 Cal. 3d 641, 463 P.2d 734, 83 Cal. Rptr. 382 (1970) (conviction reversed for violation of Dorado rule-but the underlying act still supported revocation).

21. See In re Brown, 67 Cal. 2d 339, 341, 431 P.2d 630, 632, 62 Cal. Rptr. 6, 8 (1967) (driving a car without the permission of the Authority can be adequate basis for revocation).

22. Many offenses which are charged as felonies may be treated by the sentencing judge as misdemeanors. See CaL. Penal Code $\$ 17$ (West 1970). Even where a misdemeanor alternative is not available, the judge may grant probation and impose a county jail sentence as a condition of probation. Id. $\$ 1203.1$. See id. $\S 1203$ for the few exceptions to this general rule.

23. Id. \& 1203.2(a).

24. The only exception, id. $\$ 1168$, is one by which the court, following judg- 
Thus a person who convicts himself of a felony expecting leniency may easily find himself serving the time he could have served only after conviction at trial on all counts and imposition of the maximum sentence. Defendants who realize this may feel even more pressured to plead guilty to a misdemeanor if that alternative is offered to then. Many cases, however, probably present no practical alternative, in view of the strength of the state's case, besides pleading guilty to a felony. Conviction of a lesser felony may afford the distinct advantage of a lower maximum, limiting the length of the treadmill.

The skill and diligence of one's attorney in bargaining is obviously crucial. Defense leverage stems from the attorney's diligence in exposing factual and legal weaknesses in the prosecution's case and the ability to obtain continuances by convincing clients to waive the statutory time period prescribed for bringing a case to trial. ${ }^{25}$ The pressure of a criminal calendar militates against denying the continuance. The strategy of delay designed to convince the district attorney to compromise a stale claim to move the calendar operates most favorably for those who can raise bail and do not have to remain im jail.

Defense counsel assumes in approaching negotiation that the district attorney will be reasonable simce he too knows that most penal sanctions are too harsh, unrehabilitative, and costly to impose, ${ }^{26}$ and he needs the defense bar's cooperation in moving a large caseload. ${ }^{27}$ Likewise, defense attorneys can move their caseloads efficiently, and for private attorneys with a maximum of profit, ${ }^{28}$ only by persuading their clients and the district attorney to agree to bargained dispositions. Though plea bargaining can reflect high professional skill and be of

ment and commitinent to the Department of Corrections for the routine diagnostic study, can recall the person within 120 days and resentence him as if the first sentence did not exist.

According to practitioners and jndges interviewed by the author, it is not infrequently the practice for the district attorney to move for the dismissal of the entire new prosecution once the defendant is back in prison through revocation of probation or parole. Thus, in reahty if not in legal theory, the defendant can be punished administratively for the new act. The end result of this entire process is that the defendant loses the benefit of the bargain for which he pleaded guilty and inay end up serving a full sentence that, theoretically, is pursuant to that same plea.

25. Misdemeanor cases must be brought to trial within 30 days of arraignment. Cal. Penal Code $\S 1382(3)$ (West 1970). Felony cases inust be tried within 60 days after the information or indictment is filed in Superior Court. Id. $\S 1382(2)$. By the terms of both sections, the time requirements may be waived, although the legislature has also declared a policy against granting contimuances. Id. $\$ 1050$.

26. See note 208 infra.

27. See Skolnick, Social Control in the Adversary System, 11 J. OF Confuict RESOLUTION 52 (1967). This article by a legal sociologist presents an interesting description and analysis of the guilty plea processes in Alameda County, Califorma.

28. See The Supreme Court, 1969 Term, 84 HARv. L. REV. 148, 152 (1970). 
great assistance to individual clients, there are disturbing indications that soine meinbers of the defense bar turn automatically to "dealing" their cases without researching thein or counseling their clients in a professional inanner. ${ }^{29}$

Finally, a survey of bargaining factors and roles requires recognition of the trial judge's crucial position. Once the agreeinent lias been reached it can become operative only on judicial acceptance because the district attorney does not liave the power to discontinue a prosecution in whole or in part on his own. ${ }^{30}$ Heretofore the secretiveness of plea bargaining, particularly the failure of counsel to disclose the fact, circumstances, and results of bargaining, lias prevented inany courts froin exercising supervision over the fairness of the proposed disposition. The result has been erosion of the judicial function, particularly the ability of trial and appellate courts to control the processes that affect the dispensation of justice. This erosion of judicial authority has resulted, at least to soine degree, in high-pressure prosecution tactics, incompetent defense work, unequal access to bargaining, widely disproportionate sentences for defendants similarly situated, and cynicisin towards a system that depends in part on pressure, deception, and ingratiation to achieve its results.

The widespread use of the plea bargain to alleviate a breakdown in administration las raised difficult questions concerning the judicial function. Judges have been universally cautioned against intervening directly to encourage settlement for fear of bringing too inuch pressure on the defendant's decision. ${ }^{31}$ Public response to charges of alleged lenien$\mathrm{cy}^{32}$ las lad impact in making judges more reluctant to encourage district attorneys to offer generally inore reasonable dispositions. Ironically, the People's advocate has arranged the great majority of sentences lumped by politicians and the press as "lenient." Ordinarily the district attorney becomes the intransigent adversary only wlien a case reaclies the public's attention. A "media" case presents an especially difficult problem for a judge who wisles to assure that similar cases coming before him do not differ substantially in result and are penologically sound. ${ }^{33}$

29. See, e.g., In re Williams, 1 Cal. 3d 168, 460 P.2d 984, 81 Cal. Rptr. 784 (1969), discussed in text accompanying notes 156-73 infra.

30. People v. Ward, 85 Cal. 585, 590, 24 P. 785, 786 (1890). The common law power of the prosecutor to discontinue prosecution was abolished in California in 1872. Cal. Penal Code $\$ 1386$ (West 1970).

31. See Note, Judicial Plea Bargaining, 19 Stan. L. Rev. 1082 (1967).

32. See, e.g., Justice on Trial: A Special Report, NewsweEk, Mar. 8, 1971, at 39. A nationwide cross section of 1,717 adults were asked to state what was wrong with American criminal justice. Seventy-five percent answered that convicted criminals are let off too easily. For an interesting journalistic report on plea bargaining in Cook County courts, see id. at 20-37.

33. See, e.g., People v. Beasley, 5 Cal. App. 3d 617, 85 Cal. Rptr. 501 (1st Dist. 
II

\section{Induced Convictions: The Growth of Legal Principles}

Pleading guilty in return for a supposed benefit is not new to criminal practice in California. ${ }^{34}$ The guilty plea has always been a ineans for convicting and sentencing persons without resort to trial. This section reviews the background of the guilty plea in California, the doctrine that has insulated it, and the phenomenon of the unkept plea bargain that initially forced the courts to take notice of abuses that have risen froin the practice. The transcript submission, an alternative inethod for processing California plea bargains, is also examined.

\section{A. Guilty Pleas and the Unkept Bargain}

Early in the state's history the supreine court held that guilty pleas were valid convictions. ${ }^{35}$ Over the years they became the most inviolable of convictions:

[A] confession of the offense by the party charged, by a plea of guilty, is the highest kind of conviction which the case admits, and submits him to precisely the same punishment as if he were tried and found guilty by a jury. ${ }^{36}$

The confession of guilt made personally by defendant allowed the state to pass judgment without proving its case. ${ }^{37}$ The courts have repeatedly said that the plea amounts to an admission of every elennent of the crime charged and relieves the prosecution of its burden to prove guilt beyond a reasonable doubt. ${ }^{38}$

But if confessions, whether made in court in the form of a guilty plea or out of court, were viewed primarily as demonstrations of remorse and the beginnings of rehabilitation, ${ }^{39}$ this notion was quickly tempered by reality. In 1871, the California supreme court invalidated a confession made to police officers because it was induced by an implied promise

1970). See especially id. at 640, 674-75 n.20, 85 Cal. Rptr. at 516, 542-43 n.20. (Sims, J., dissenting).

34. See People v. Aseltine, 139 Cal. App. 768, 770, 34 P.2d 830, 831-32 (2d Dist. 1934); Miller, The Compromise of Criminal Cases, 1 S. CAL. L. REv. 1 (1927); Moley, The Vanishing Jury, 2 S. CAL. L. REv. 99 (1928).

35. People v. Goldstein, 32 Cal. 432, 433 (1867). See also Hallinger v. Davis, 146 U.S. 314, 318 (1892); People v. Noll, 20 Cal. 164, 165 (1862).

36. People v. Hickman, 204 Cal. 470, 476, 268 P. 909, 912 (1928).

37. See People v. McCrory, 41 Cal. 458, 461 (1871).

38. E.g., People v. Ward, 66 Cal. 2d 571, 575, 426 P.2d 881, 883, 58 Cal. Rptr. 313, 315 (1967); People v. Jones, 52 Cal. 2d 636, 650-51, 343 P.2d 577, 586 (1959); People v. Whitton, 112 Cal. App. 2d 328, 333, 246 P.2d 60, $63-64$ (2d Dist. 1952).

39. The notion that a guilty plea should be the product only of the defendant's remorse had a remarkably long life. See Meyer v. Uuited States, 424 F.2d 1181, 1193 (8th Cir. 1970) (Lay, J., dissenting). 
of leniency in the conviction and sentence that would follow. ${ }^{40}$ The prosecutorial practice of inducing pleas became apparent through proof of unkept promises. In one notable case a grand juror, with the district attorney's knowledge, promised a defendant no more than a fine if she would give testimony against a co-defendant and plead guilty to jury tampering. Instead, the judge sentenced her to state prison upon entry of the guilty plea. The supreme court set aside the conviction saying:

Too much may not be done to purify and keep pure the administration of justice. If a defendant could not rely upon a covenant made with her by the head of the cominittee of the grand jury and the office of the district attorney, then indeed would our whole system of legal procedure be brought under the cloud of suspicion. It is far better that one woman go unpunished than that it be said that the officers of the law in charge of the prosecution of crimes may play fast and loose with their promises to defendants under indictment. ${ }^{41}$

Significantly, the court did not condemn the promise of leniency per se. It would have been a simple task analytically to invalidate guilty pleas that were the product of prosecutorial promises. As with confessions induced by the police, the state has operated purposefully to influence the individual to pronounce his guilt. Perhaps it was thought that entry of the guilty plea in open court before a judicial officer was protection enough against coercion by the police or the prosecution. But in practice the judge was ordinarily ignorant of matters that preceded entry of the plea and could reasonably assume that defendant had only hoped for leniency. No procedures existed for cliecking the accuracy and reliability of the confession or the factors that motivated it. The entry proceeding was a formality that took two to three ininutes in court and revealed nothing beyond the fact that defendant answered "yes" to the question of whether he wished to plead guilty to the charges that the district attorney insisted on pressing. ${ }^{42}$

\section{B. The Insulation of the Guilty Plea}

Apart from the unkept plea bargain, the legal doctrine that grew up around the guilty plea substantially immunized these convictions. After a judgment the plea could be set aside only if "on account of duress, fraud, or other force overreaching the free will and judgment of a defendant, he is deprived of his right to a trial on the inerits." ${ }^{\text {33 }}$

40. People v. Johnson, 41 Cal. 452,454 (1871).

41. People v. Schwarz, 201 Cal. 309, 314, 257 P. 71, 73 (1927).

42. In re Tahl, 1 Cal. 3d 122, 138, 460 P.2d 449, 461, 81 Cal. Rptr. 577, 589 (1969) (Peters, J., concurring and dissenting).

43. In re Hough, 24 Cal. 2d 522, 531, 150 P.2d 448, 453 (1944). For example, a 
Most petitioners experienced considerable difficulty in producing such a showing since the entry of the judgment and the silence of the trial court record were presumed to indicate a voluntary plea. ${ }^{44}$ A defendant with counsel was presumed to know the nature of the charge against him and the consequences of pleading guilty. ${ }^{45}$ Reliance upon the advice $^{46}$ or even the "wilfully false stateinents" not warrant relief. A "responsible" state officer must liave made the assurances that induced the plea and were unfulfilled; a public defender did not qualify even though he was paid out of public monies. ${ }^{48}$

It becaine increasingly clear, however, that prosecutors in addition to overt promises were inducing convictions through suggestive statements or conduct that led defense attorneys to make positive representations to their clients that later proved groundless. A person who did not liave the assistance of counsel was even more susceptible to this type of influence. ${ }^{49}$ In 1944 the supreme court held that relief might be had where a person's will to defend himself had been overcome through good faith reliance on representations made by his attorney that were "apparently substantially corroborated" by the acts or stateinents of a "responsible" state official, particularly a judge or a prosecutor. ${ }^{50}$ The law in this respect lias progressed no farther. No California court has ever attempted to explain how a confession of guilt can be voluntary in any meaningful sense when it is the product of defense counsel's out-

plea entered in order to stop the worrying and crying of the defendant's daughters about the possibility of his going to the gas chamber did not constitute duress warranting rehief. People v. Toth, 224 Cal. App. 2d 130, 132, 36 Cal. Rptr. 417, 418 (1st Dist.), cert. denied, 377 U.S. 983 (1964).

44. People v. Martinez, 154 Cal. App. 2d 233, 236, 316 P.2d 14, 15 (1st Dist. 1957); People v. Paraskevopolis, 42 Cal. App. 325, 327, 183 P. 585, 586 (3d Dist. 1919). The entry of the judgment in the minutes was sufficient indication that the judge had performed his responsibilities. Ex parte Woods, 41 P. 796 (1895); Ex parte Haase, 5 Cal. App. 541, 545, 90 P. 946, 948 (3d Dist. 1907).

45. In re Tahl, 1 Cal. 3d 122, 128, 460 P.2d 449, 453, 81 Cal. Rptr. 577, 581 (1969); see, e.g., People v. Reeves, 64 Cal. 2d 766, 773 n.4, 415 P.2d 35, 38 n.4, 51 Cal. Rptr. 691, 694 n.4 (1966). See also People v. Gayton, 10 Cal. App. 3d 178, 181, 88 Cal. Rptr. 891, 893 (1st Dist. 1970).

46. People v. Manriquez, 188 Cal. 602, 605-06, 206 P. 63, 64 (1922); People v. Miller, 114 Cal. 10, 16, 45 P. 986,987 (1896).

47. People v. Gilbert, 25 Cal. $2 \mathrm{~d} 422,443,154$ P.2d 657, 668 (1944). See also People v. Ribero, 4 Cal. 3d 55, 62, 480 P.2d 308, 312, 92 Cal. Rptr. 692, 696 (1971) (dictum).

48. In re Hough, 24 Cal. 2d 522, 527-29, 150 P.2d 448, 451-52 (1944). The notion that the state action doctrine of the fourteenth amendment prevents the granting of relief for reliance on representations made by defense counsel has been severely criticized. See Wilson v. Rose, 366 F.2d 611, 615-16 (9th Cir. 1966) (opinion by Browning, J.).

49. Cf. Miller, supra note 34, at 21.

50. People v. Gilbert, 25 Cal. 2d 422, 443, 154 P.2d 657, 667 (1944). 
right lie, distortion, or honest but mistaken representation, regardless of whether the state has led on the defendant. ${ }^{51}$

The most frequent focal point of challenge to guilty plea convictions, until recently, has been the statute under which the trial judge, following a guilty plea, could fix the degree of a crime if the penal section at issue contemplated different levels of gravity. ${ }^{52}$ Convicted persons who sought relief often asserted a pre-entry claim that they were con victing themselves of the lesser degree, or the higher degree but for a lesser punishment.53 Many persons said simply that they were ignorant of what they were pleading to or the judge's power to detcrmine the degree. $^{54}$ Unkept promises also may have been a factor. Since trial judges were under no duty to advise or elicit the understanding of defendants regarding the charges, their rights, the consequences of their pleas, or the factors that influenced them, ${ }^{55}$ denial of rehef at the appellate level was routine when the prisoner could not show an unkept plea bargain or a gross denial of due process. ${ }^{56}$ Again, the usual presumption was that petitioners had merely hoped for leniency when entering their pleas and could not complain because disappointed. ${ }^{57}$

Fairness in degree-determination proceedings was greatly enhanced when the supreme court ruled that persons who plead guilty to a crime divided into degrees are "entitled to the same basic constitutional gnarantees and the prosecution lield to the saine burden of proof as in a case in which the defendant pleads not guilty."58 The sufficiency of the evidence and the introduction of inadmissible testimony are particularly subject to review. ${ }^{59}$ By the time of this ruling, however, the legislature began to take a more forthright approach to the emerging system of plea bargain-

51. See text accompanying notes 170-73 infra.

52. Cal. Penal Code $\$ 1192$ (West 1970):

Upon a plea of guilty, or upon conviction by the court without a jury, of a crime distinguished or divided into degrees, the court must, before passing sentence, determine the degree. Upon the failure of the court to so determine, the degree of the crime of which the defendant is guilty, shall be deeined to be of the lesser degree.

53. See, e.g., People v. Martin, 48 Cal. App. 2d 514, 516, 119 P.2d 1008, 1009 (2d Dist. 1941).

54. See, e.g., People v. McCoy, 195 Cal. App. 2d 570, 572, 15 Cal. Rptr. 924, 925

(3d Dist. 1961); People v. Smith, 120 Cal. App. 2d 531, 533-34, 261 P.2d 306, 307-08,

(2d Dist. 1953).

55. In re Tahl, 1 Cal. 3d 122, 127, 460 P.2d 449, 452, 81 Cal. Rptr. 577, 580

(1969); People v. Mendez, 27 Cal. 2d 20, 22, 161 P.2d 929, 930 (1945).

56. See, e.g., People v. Martinez, 154 Cal. App. 2d 233, 235-37, 316 P.2d 14, 16-17 (1st Dist. 1957).

57. See, e.g., People v. Gottlieb, 25 Cal. App. 2d 411, 415, 77 P.2d 489, 491 (2d Dist. 1938); People v. Aseltine, 139 Cal. App. 768, 771, 34 P.2d 830, 832 (2d Dist. 1934).

58. People v. Ward, 66 Cal. 2d 571, 576, 426 P.2d 881, 883-84, 58 Cal. Rptr. 313, 315-16 (1967).

59. Id. at 576, 426 P.2d at 884,58 Cal. Rptr. at 316. 
ing. A defendant charged with an offense carrying degrees could-with the district attorney's consent and the court's approval-tie his guilty plea to a specified degree and thus limit his punishment. ${ }^{80}$

In addition the defendant could specify his punishment, subject to prosecutorial and judicial approval, if charged with a crime for which the jury had the power to recommend or impose punishment. ${ }^{61}$ Pleas of guilty entered pursuant to these provisions were deeined withdrawn and were inadmissible in subsequent proceedings if the court disapproved of the bargain before it entered judgment. ${ }^{62}$ Thus the legislature overtly encouraged plea bargaining in a small but important range of offenses including robbery, ${ }^{63}$ burglary, ${ }^{64}$ and murder, ${ }^{65}$ but the protection it initially provided did not extend to the broad range of offenses. A 1970 addition to the Penal Code permits conditioned pleas, with protections, for almost all offenses. ${ }^{66}$

Guilty pleas have proved largely obdurate to attack despite the abuses that have arisen from plea bargaining. The right to appeal guilty pleas for invalidity depends on obtaining a certificate of probable

60. Cal. Penal Code $\$ 1192.1$ (West 1970).

61. Ch. 1297, § 3, [1957] Cal. Stat. 2616, as amended, Cal. Penal Code $\$ 1192.5$ (West Supp. 1971); see note 66 infra and accompanying text. An example of a sentence for jury choice is death or life imprisonment for murder, as provided by CAL. Penal Code $\$ 190$ (West 1970).

62. Cal. Penal Code $\S 1192.4$ (West Supp. 1971). It shonld be carefully noted that statements that defendant makes after entry of this plea-for example, to a probation officer-may be admissible even though the plea is later withdrawn. People v. Alesi, 67 Cal. 2d 856, 861-62, 434 P.2d 360, 363, 64 Cal. Rptr. 104, 107 (1967) (admissions made to probation officer solely on defense attorney's advice). But if the admissions are induced by official misrepresentations as to ehgibility for or likelihood of receiving certain kinds of correctional treatment, such as a narcotics rehabilitation prograin, they may be inadmissible. Id. Admissions which result from the probation officer's threats not to recommend probation are inadmissible. People v. Quinn, $61 \mathrm{Cal} .2 \mathrm{~d}$ 551, 554, 393 P.2d 705, 707, 39 Cal. Rptr. 393, 395 (1964).

63. Caz. Penal Code $\S 211 a$ (West 1970).

64. $I d . \S 460$.

65. $I d . \$ 189$.

66. Upon a plea of guilty or nolo contendere to an information or indictment, the plea may specify the punishment to the same extent as it may be specified by the jury on a plea of not guilty or fixed by the court on a plea of guilty, nolo contendere, or not guilty, and inay specify the exercise by the court thereafter of other powers legally available to it.

Where such plea is accepted by the prosecuting attorney in open court and is approved by the court, the defendant, except as otherwise provided in this section, cannot be sentcnced on such plea to a punishment more severe than that specified in the plea, and the court may not proceed as to such plea other than as specified in the plea.

If the court approves of the plea, it shall inform the defendant prior to the making of the plea that (1) its approval is not binding, (2) it nay, at the time set for the hearing on the application for probation or pronouncement of judginent, withdraw its approval im the light of further consideration of the matter, and (3) in such case, the defendant shall be permitted to withdraw his plea if he desires to do so. The court shall also cause an inquiry to be 
cause from the court that rendered judgment. ${ }^{\text {BT }}$ The trial courts have been unwilling to issue these certificates. ${ }^{68}$ And they have been reluctant to allow withdrawal of pleas prior to judgment ${ }^{30}$ despite unrestricted authority to grant these motions. ${ }^{70}$ The appellate courts have repeatedly urged trial courts to grant this relief, ${ }^{71}$ which has the effect only of al-

made of the defendant to satisfy itself that the plea is freely and voluntarily made, and that there is a factual basis for such plea.

If such plea is not accepted by the prosecuting attorney and approved by the court, the plea shall be deemed withdrawn and the defendant may then enter such plea or pleas as would otherwise have been available.

If such plea is withdrawn or deemed withdrawn, it may not be received in evidence in any criminal, civil, or special action or proceeding of any nature, including proceedings before agencies, commissions, boards, and tribunals.

Id. § 1192.5 (West Supp. 1971).

The supreme court had already recognized a legislative policy to encourage generally the settlement of criminal cases and ruled in accordance that withdrawn pleas were madmissible in subsequent proceedings, though, depending on the facts, they might not constitute prejudicial error if admitted erroneously at trial. People v. Hamilton, $60 \mathrm{Cal}$. 2d 105, 114, 383 P.2d 412, 416-17, 32 Cal. Rptr. 4, 8 (1963). In California all properly withdrawn guilty pleas are inadmissible in subsequent proceedings whatever their nature. CAL. EVID. CODE $\$ 1153$ (West 1970).

67. CaI. Penal CODE $\S 1237.5$ (West 1970). The purpose of this section, according to the cases, is to deter frivolous attack upon guilty pleas by limiting appeal to situations where fundamental errors have occurred, such as lack of jurisdiction. People v. Ward, 66 Cal. 2d 571, 575, 426 P.2d 881, 882-83, 58 Cal. Rptr. 313, 314-15 (1967). The court ruled later that this section must be complied with when challenging the plea's validity but not when challenging errors that occurred subsequent to the plea's entry, such as sentencing in excess of a plea bargain. People v. Delles, $69 \mathrm{Cal} .2 \mathrm{~d} \mathrm{906,909,447}$ P.2d 629, 631, 73 Cal. Rptr. 389, 391 (1968). Compliance is not required in other circumstances when challenging denial of a motion to suppress evidence [People v. West, 3 Cal. 3d 595, 601, 477 P.2d 409, 411, 91 Cal. Rptr. 385, 387 (1970); Moran v. St. John, 267 Cal. App. 2d 474, 477-78, 73 Cal. Rptr. 190, 193 (4th Dist. 1968)], or refusal to dismiss after the prosecution's failure to bring defendant to trial within the time required by law [People v. Brown, $260 \mathrm{Cal}$. App. 2d 745, 746-47, 67 Cal. Rptr. 288, 289 (2d Dist. 1968)]. But the supreme court recently indicated what appears to be a hardening attitude towards comphance with section 1237.5. See People v. Ribero, 4 Cal. 3d 55, 62, 480 P.2d 308, 314, 92 Cal. Rptr. 692, 698 (1971).

68. In an apparent attempt to counteract this reluctance, the supreme court said recently that the requirement is designed to eliminate allegations that are "clearly frivolous and vexatious" but not those that involve an "honest difference of opinion." People v. Ribero, 4 Cal. 3d 55, 63 n.4, 480 P.2d 308, 313 n.4, 92 Cal. Rptr. 692, 697 n.4 (1971).

69. See, e.g., People v. Gottlieb, 25 Cal. App. 2d 411, 414-15, 77 P.2d 489, 49091 (2d Dist. 1938); People v. Pavaskevopolis, 42 Cal. App. 325, 330, 183 P. 585, 587 (3d Dist. 1919). See also People v. Nixon, 34 Cal. 2d 234, 236, 209 P.2d 385, 386 (1949).

70. Cal. Penal Code $\$ 1018$ (West 1970). Prior to the judgment, a court may permit at any time, in its discretion, a plea of guilty to be withdrawn and a plea of not guilty to be substituted. People v. Griggs, 17 Cal. 2d 621, 624, 110 P.2d 1031, 1033 (1941).

71. See, e.g., People v. Miller, 114 Cal. 10, 16, 45 P. 986, 987 (1896); People v. McCrory, 41 Cal. 458, 462 (1871):

[W] hen there is reason to believe that the plea has been entered through inadvertence, and without due dehiberation, or iguorantly, and maimly from the hope that the punishment, to which the accused would otherwise be exposed, 
lowing defendant to plead anew and proceed to trial, but have seldoun reversed trial judges for disallowing withdrawal. ${ }^{72}$

\section{The Transcript Submission}

The transcript submission is an alternative form for processing bargained dispositions in California used largely when defendants are unwilling to confess their guilt. In accordance with a stipulation negotiated between counsel in felony cases, defendant submits the transcript of his preliminary hearing for judgment in return for some consideration in conviction or sentence. The theory of transcript submission is that the defendant presents a dispute for judicial resolution but limits his defense to whatever was presented at the preliminary hearing or appears from a reading of the transcript. ${ }^{73}$ But preliminary hearings are ordi-

may thereby be mitigated, the Court should be indulgent in permitting the plea to be withdrawn.

72. The denial of a motion to withdraw is not appealable but may be reviewed for abuse of discretion if an appeal from judgment is properly taken under CAI. PENAI CODE \$1237.5 (West 1970). People v. Ribero, 4 Cal. 3d 55, 62, 480 P.2d 308, 313, 92 Cal. Rptr. 692, 697 (1971). But judicial "[d]iscretion is abused only when '. . . the court exceeds the bounds of reason, all of the circumstances before it being considered. . . ." People v. McDonough, 198 Cal. App. 2d 84, 90, 17 Cal. Rptr. 643, 646 (5th Dist. 1961). Relief has been granted by the appellate courts in the following circumstances: sentencing in excess of a bargain that the judge himself had made with defendant [People v. Delles, 69 Cal. 2d 906, 910, 447 P.2d 629, 632, 73 Cal. Rptr. 389, 392 (1968)]; defense counsel's assurances of life imprisonment instead of death, corroborated by statements of the prosecutor [People v. Griggs, 17 Cal. 2d 621, 624, 110 P.2d 1031, 1033 (1941) J; entry of plea after denial of motion for continuance in order that defense witnesses might arrive [People v. McCrory, 41 Cal. 2d 458, 461-62, (1871)].

When the 10-day time period [CAL. R. CT. 31d] for filing a notice of appeal under Cal. Penal Code $\$ 1237.5$ (West 1970) has run, and relief from failure to file under rule 31a las not been granted by an appellate court [see People v. Ribero, 4 Cal. 3d 55, 65, 480 P.2d 308, 314-15, 92 Cal. Rptr. 692, 698-99 (1971)], the alternatives left open to defendant are petitions for the writs of coram nobis or habeas corpus. The writ of coram nobis has the purpose of allowing the trial court to vacate its judgment when, one, facts are shown that existed at the time of judginent and would have prevented rendition of the judgment if revealed to the court; two, failure to bring the facts to the court's attention was not petitioner's fault, that petitioner did not know of the facts and could not with due ditigence discover them, and he acted with due diligence upon discovering them; and three, the newly discovered facts do not go to the merits of issues already tried. People v. Shipınan, 62 Cal. 2d 226, 230, 397 P.2d 993, 995, 42 Cal. Rptr. 1, 3 (1965); People v. Smith, 120 Cal. App. 2d 531, 534, 261 P.2d 306, 308 (2d Dist. 1953); see, e.g., People v. Wadkins, 63 Cal. $2 \mathrm{~d} 110,113,403$ P.2d 429, 432, 45 Cal. Rptr. 173, 176 (1965) (unkept plea bargain). Concerning the requirement of due diligence, sce People v. Welcl, 61 Cal. 2d 786, 793, 394 P.2d 926, 931, 40 Cal. Rptr. 238, 243 (1964) (defendant pled guilty to first degree inurder unaware that he had suffered brain damage that might lave supported insanity defense).

73. The transcript submission has raised a great deal of confusion among trial court judges as to whether the defendant imtends to present a "bona fide" defense-and, if so, how to inform him of his rights and the limited nature of the proceeding without prejudging the issue of guilt-or whether it actually represents defense counsel's unilateral decision to find an alternative to trial when defendant is unwilling to plead guilty. 
narily so routine and cross-examination so perfunctory that they reveal not the slightest defense unless the prosecution witness is completely non-credible. Usually the only witness called is the arresting officer, who is experienced at testifying. And apparently defense counsel often do not prepare themselves well for preliminary hearings or for reasons of "strategy" do not wish to "show their hand" at this stage. ${ }^{74}$

One of the dangers of transcript submission is that defendant may see it as a trial on the merits whereas it is largely an administrative device functionally equivalent to a guilty plea in most instances. ${ }^{75}$ But important differences remain. Even though the proceeding is not truly a court trial, the defendant has not confessed his guilt and, according to existing California law, retains his right to appeal the sufficiency of the evidence supporting conviction. ${ }^{76}$ Ordinarily these appeals do not result in reversal due to the one-sided, practically unchallenged nature of the state's case at the preliminary hearing. ${ }^{77}$ The ambiguities of the transcript submission reveal even more sharply the need for advising a defendant of his rights and supervising the process by which transcript submissions and guilty pleas are obtained.

\section{III}

\section{SUPERVISING THE TRADE}

In Brady v. United States ${ }^{78}$ the United States Supreme Court removed the constitutional fears about the process of plea bargaining, ruling that a guilty plea is not invalid under the fifth amendment solely be-

See the panel discussion on guilty pleas and transcript submissions at the 1970 Sentencing Institute for Superior Court Judges, 93 Cal. Rptr. app. $52-57$ (1970).

74. It is difficult to understand the justifications based on strategy since trial is ordinarily considered a remote possibility and because the revelation of a defense case can only serve to increase bargaiming leverage.

75. The suprome court has recognized this. In re Mosley, $1 \mathrm{Cal} .3 \mathrm{~d} 913,926,464$ P.2d 473, 480-81, 83 Cal. Rptr. 809, 816-17 (1970).

76. See text accompanying note 37 supra; see, e.g., People v. Reilly, 3 Cal. 3d 421, 475 P.2d 649, 90 Cal. Rptr. 417 (1970).

77. See, e.g., People v. Reilly, 3 Cal. 3d 421, 475 P.2d 649, 90 Cal. Rptr. 417 (1970), which upheld the conviction on a transcript submission in the face of a reversal by the court of appeals. The lower appellate court had found that the evidence contained in the preliminary transcript was not substantial enough to support a finding of guilt beyond a reasonable doubt. But the supreme court treated the submission, though it did not mention this approach, as a guilty plea. This conclusion must be garnered from the court's observation that the defendant had chosen not to produce any witnesses in his own behalf without any questions being raised as to why this might be so. $3 \mathrm{Cal} .3 \mathrm{~d}$ at 424,475 P.2d at $650,90 \mathrm{Cal}$. Rptr. at 418 . The opinion sheds no light on whether defendant believed loo was pleading guilty or wanted some sort of trial on the merits. This case, through its various stages, illustrates the transcript submission's fundanental ambiguities and its potential for deceiving defendants and judges alike. See note 144 infra and accompanying text.

78. 397 U.S. 742, 751 (1970), noted in 84 HARV. L. REv. 148 (1970). 
cause it is motivated by assurances of leniency. Aside from an unkept plea bargain, a guilty plea is not constitutionally involuntary unless, one, the defendant was mentally incompetent, feared punishment, or hoped for leniency so inuch that he could not, even with the help of counsel, rationally weigh his alternatives, or, two, if the state procured the conviction through physical or mental coercion which overcame the person's will. ${ }^{79}$ While Brady thus upholds the constitutionality of plea bargaining per se, other decisions make it clear that the bargaining process unust meet certaim requirements in order to survive attack on due process grounds. Initially the decisions have focused upon the judge's role at guilty plea entry proceedings.

\section{A. Securing the Record}

In Boykin v. Alabama ${ }^{80}$ the United States Supreme Court clearly enunciated the constitutional standard for entry of the guilty plea. It must be entered with "full understanding of what the plea connotes and of its consequences." The judge is directed to assemble an "affirmative" record of the proceedings. ${ }^{82}$ The court will not presume a waiver of the defendant's rights from a silent record..$^{83}$

The prophylactic measures outlined by Boykin correspond with those of Federal Rule of Criminal Procedure 11, which governs entry proceedings im federal courts and requires the trial judge to personally ascertaim the defendant's understanding of the nature of the charge. and the consequences of his plea. ${ }^{84}$ The Court explicated the rationale and dimensions of the federal rule in McCarthy $v$. United States, ${ }^{85}$ dwelling in particular on the importance of the personal judicial exami-

79. 397 U.S. at 750. The Court determined in decisions handed down the same day as Brady that the presence of a coerced confession does not invalidate a guilty plea unless the coercion has "abiding impact" on the defendant's decision to plead guilty [McMann v. Richardson, 397 U.S. 759, 767 (1970). Accord, In re Cowans, 2 Cal. 3d 733, 470 P.2d 635, 87 Cal. Rptr. 499 (1970)]; and that a guilty plea is not involuntary because induced by a state statute that provides a lower maximum penalty on a plea of guilty than the penalty authorized after a verdict of guilty by a jury. Parker v. North Carolina, 397 U.S. 790, 794 (1970).

80. 395 U.S. 238 (1969).

81. Id. at 244.

82. Id. at 242 .

83. Id. at 243, noted in 83 HARv. L. Rev. 181 (1969).

84. A defendant may plead not guilty, guilty or, with the consent of the court, nolo contendere. The court may refuse to accept a plea of guilty, and shall not accept such plea or a plea of nolo contendere without first addressing the defendant personally and determining that the plea is made voluntarily with understanding of the nature of the charge and the consequences of the plea. ... The court shall not enter a judgment upon a plea of guilty unless it is satisfied that there is a factual basis for the plea.

Fed. R. CRIM. P. 11.

85. 394 U.S. 459 (1969). 
nation in protecting the voluntariness of guilty pleas. ${ }^{86}$ In reading the McCarthy-Rule 11 protections explicitly into the constitution, though it did not mention the factual basis requirement also provided by the rule ${ }^{87}$ the Court in Boykin was remarkably cognizant of the quality of justice in the marketplace of the criminal courts: "Ignorance, incomprehension, coercion, terror, inducements, subtle or blatant threats might be a perfect cover-up of unconstitutionality." 88

The California supreme court addressed the problem of effectuating Boykin's requirement in In re Tahl. ${ }^{89}$ Petitioner Tahl pleaded guilty to first degree murder after a jury had been impaneled in his case; thereafter a jury sentenced him to death. The supreme court observed that the circumstances surrounding the guilty plea demonstrated, at the very least, defendant's awareness of his right to jury trial and the significance of waiving it since the jury for him was no longer an "esoteric concept" but an "existential reality." No Nevertheless, the court found in Boykin a prohibition against implied waivers by a plea of guilty, however plausible. ${ }^{91}$ The court held that the record of a guilty plea proceeding:

must contain on its face direct evidence that the accused was aware, or made aware, of his right to confrontation, to jury trial, and against self-imcrimination, as well as the nature of the charge and the consequences of his plea. ${ }^{92}$

It acknowledged that in some circumstances the trial court might not be required to explain the significance of one or several of the three basic rights to the defendant. ${ }^{93}$ On the Tahl facts, for example, the "existential reality" of seeing a jury face to face might obviate the necessity of explaining the significance of foregoing trial. But the California court explicitly requires defendant's express waiver of each of the three rights whatever the circumstances of the case..$^{94}$

86. Id. at 467.

87. See note 84 supra.

88. 395 U.S. at $242-43$.

89. 1 Cal. 3d 122, 460 P.2d 449, 81 Cal. Rptr. 577 (1969).

90. Id. at 131, 460 P.2d at 455-56, 81 Cal. Rptr. at 583-84.

91. Id. at 131-32, $460 \mathrm{P} .2 \mathrm{~d}$ at $456,81 \mathrm{Cal}$. Rptr. at 584.

92. Id. at 132,460 P.2d at 456,81 Cal. Rptr. at 584.

93. Id.

94. Id. Boykin's prophylactic requirements have been held to be prospective only by every court that has considered the matter. E.g., id. at 133, 460 P.2d at 457, $81 \mathrm{Cal}$. Rptr. at 585. See also Moss v. Craven, 427 F.2d 139 (9th Cir. 1970). But the constitutionality of guilty pleas depends more fundamentally on their knowing and intelligent nature - and this was the standard for waiver of constitutional rights prior to Boykin. See McCarthy v. United States, 394 U.S. 459, 466 (1969). See also Brady v. United States, 397 U.S. 742,749 (1970). The most basic rights waived by a guilty plea are jury trial, confrontation, and the privilege against self-incrimmation. It would seem that relief should be granted for invalid waiver (despite Boykin's prospectivity) 
The rules of Boykin and Tahl seek to insure that a defendant will reach a decision that is truly his, not one based solely on his attorney's assurances or induced by improper state conduct. The judge, impartial and authoritative, has the responsibility for ascertaining whether the defendant has reached an intelligent decision to convict himself, knowing and understanding his rights, the nature of the offenses charged, and the consequences that will flow from his conviction.

Informing defendant of the "consequences" should mean that the judge inust review for the defendant the sentencing alternatives which are not precluded by the bargain and the imphications of the disposition agreed to, including the conviction's collateral effects, such as ineligibility for probation, ${ }^{95}$ parole, or special correctional programs, ${ }^{96}$ and the fact that certain proceedings can be initiated following the convictionfor example, those to determine whether the person is a mentally disordered sex offender. ${ }^{97}$ An explanation of the nature of probation, the function of the Adult Authority in the scheme of indeterminate sentencing, and the grounds for and consequences of revocation of probation or parole is especially critical in California. ${ }^{98}$ All these consequences and their ramifications are precisely the kind of information that a defendant needs to know in order to decide intelligently whether to forego trial.

Fulfilling the judicial role enunciated by Boykin and Tahl helps to guard against the precipitous decision that a person may make when he is caught in the tunnel of criminal prosecution and sees only the

when petitioner can show that his plea was not "intelligent," that is, that despite counsel's presence he did not understand the nature of the charge or the consequences of his plea.

95. See Munich v. United States, 337 F.2d 356 (9th Cir. 1964) (relief granted for counsel's good faith but legally erroneous assurance that a guilty plea to the particular offense would not preclude eligibility for probation).

96. E.g., a narcotics rehabilitation program. See People v. Ribero, 4 Cal. 3d 55, 59, 480 P.2d 308, 310, 92 Cal. Rptr. 692, 694 (1971) (defendant asserted that defense counsel had promised he would be placed in a hospital for treatment following entry of his plea).

97. Upon conviction for any offense the judge, on his own motion or on motion of the prosecutor, may suspend criminal proceedings against the defendant if it appears to his satisfaction that there is probable cause for believing the defendant to be a mentally disordered sex offender. CAL. WeLf. \& INST'NS CODE $\S 6321$ (West Supp. 1971). A whole series of consequences may follow. Of greatest concern, defendant may end up incarcerated for an indefimite term in a state prison if he is certified, after certain proceedings, as not amenable to treatment. Id. $\S 6316$. When he is released, lie must register as a sex offender and reregister whenever he changes his address. CaI. PENAL CODE $\$ 290$ (West 1970). The entire inentally-disordered-sex-offender-procedures are set out in CAL. WeLF. \& INST'NS CODE $\$ \$ 6300-30$ (West Supp. 1971); see Comment, The MDSO-Uncivil Civil Commitment, 11 Santa Clara LAw. 169 (1970). These proceedings, it must be repeated, cannot be initiated until defendant convicts himself or is convicted at trial.

98. See text accompanying notes 11-12, 17-24 supra. 
light of a quick and apparently less painful way out. But there is the danger that guilty plea proceedings, even if these rules are scrupulously adhered to, may become only slightly more formalized processes which mask the need for judicial scrutiny of the state's concerted effort to extract convictions. In People $v$. West ${ }^{90}$ the California supreme court has taken one important step towards alleviating part of this fear by requiring that the terms of all plea bargains appear on the record. ${ }^{100}$ This rule is apparently designed to force disclosure of the nature and extent of bargaining and its results so that the judge can check the soundness and fairness of the result reached between counsel. ${ }^{101}$ The primciple underlying this requirement can be seen as that of lolding the executive branch accountable to the judiciary for use of the charging function, among other tools, to pressure individuals to convict themselves. ${ }^{102}$

\section{B. Checking the Factual Basis}

In McCarthy $v$. United States ${ }^{\mathbf{1 0 3}}$ the United States Supreme Court directed federal judges in following Federal Rule of Criminal Procedure 11 to ascertain personally the factual basis for guilty pleas. ${ }^{104}$ This examination of the relation among the facts, the law, the charges, and defendant's admissions, as represented by the plea or expressed verbally, is especially important to determining defendant's understanding regarding the legal eleinents of the charges in relation to the facts of his case and whether his conduct actually falls within the charges. ${ }^{105}$ The crime of tax evasion at issue in McCarthy, for exaunple, requires specific intent, ${ }^{106}$ the defendant might not know, unless informed at the entry of the plea, ${ }^{107}$ that the prosecution's failure to prove this eleinent would reduce his offense to violation of two closely related offenses that were only misdemeanors. ${ }^{108}$

99. 3 Cal. 3d 595, 477 P.2d 409, 91 Cal. Rptr. 385 (1970).

100. Id. at 609, $477 \mathrm{P} .2 \mathrm{~d}$ at 417,91 Cal. Rptr. at 393. This requirement has prospective application only. Id. at 611, 477 P.2d at 419, 91 Cal. Rptr. at 395. The Ninth Circuit also requires that plea bargains be exposed for the record. Jones v. United States, 423 F.2d 252, 255 (1970).

101. See 3 Cal. 3d at 599, 477 P.2d at $410,91 \mathrm{Cal}$. Rptr. at 386.

102. This principle seems to underly the court's discussion about decisions in the federal courts that have set aside guilty pleas, even though the bargains had been consummated, because the prosecution had used coercive tactics. $1 d$. at $610,477 \mathrm{P} .2 \mathrm{~d}$ at 418, 91 Cal. Rptr. at 394.

103. 394 U.S. 459 (1969).

104. Id. at 467.

105. Id.

106. 26 U.S.C. $\$ 7201$ (1964) (wilfully and knowingly attempting to evade tax payments).

107. 394 U.S. at 471 .

108. 26 U.S.C. $\$ 7203$ (Supp V, 1970) (wilfull failure to pay taxes); 26 U.S.C. $\S 7207$ (Supp V, 1970) (wilfully filing a fradulent or false return). 
Neither Boykin v. Alabama, ${ }^{109}$ In re Tahl, ${ }^{110}$ nor Brady v. United States $^{111}$ explicitly required state trial courts to check the factual basis for guilty pleas, but this rule has been added to California law by the recently enacted section $1192.5^{112}$ of the California Penal Code. And Brady suggests that it does have a constitutional dimension. In rejecting the claim that Brady's plea was invalid because entered only to avoid the death penalty, the Court stated succinctly wly it believed that he had not been faced witl an impermissible burden:

We would have serious doubts about this case if the encouragement of guilty pleas by offers of leniency substantially increased the likelihood that defendants, advised by competent counsel, would falsely condemn themselves. But our view is to the contrary and is based on our expectations that courts will satisfy themselves that pleas of guilty are voluntarily and intelligently made by competent defendants with adequate advice of counsel and that there is nothing to question the accuracy and reliability of defendants' admissions that they coinmitted the crimes with which they are charged. ${ }^{113}$

The Court's admonition to trial courts concerning the accuracy and rehability of defendants' admissions can only be construed reasonably, in light of Boykin's assimilation of McCarthy, ${ }^{114}$ as imposing the factual basis requirement. The requirement does not nean that the trial judge caimot accept the plea when he finds lack of sufficient correlation between the legal elements of the offense and the facts of the case before him. The factual basis examination is designed to protect defendants from being induced or coerced into pleading to offenses that they could not have been convicted of at trial. ${ }^{115}$ If after proper notice defendant nevertheless wishes to convict himself, the court can accept the plea.

This important concept of notice to be given by the trial judge at the entry proceeding becomes apparent in studying the California supreme court's resolution of an allied problem in People $v$. West. ${ }^{116}$ Defendant was charged with possession of marijuana. ${ }^{117}$ In order to obtain a sentence more flexible and fair than that provided by the proper

109. 395 U.S. 238 (1969).

110. 1 Cal. 3d 122, 460 P.2d 449, 81 Cal. Rptr. 577 (1969).

111. 397 U.S. 742 (1970).

112. Cal. Penal Code $\$ 1192.5$ (West Supp. 1971); see note 66 supra.

113. 397 U.S. at 758.

114. See text accompanying notes 85-88 supra.

115. See text accompanyimg notes 105-08 supra.

116. 3 Cal. 3d 595, 477 P.2d 409, 91 Cal. Rptr. 385 (1970).

117. Cal. Heatth \& SAFETY CoDE $\$ 11530$ (West Supp. 1971). At the time of the offense, possession of marijuana was punishable only by a sentence of 1-10 years. Ch. 274, $\S 7$, [1961] Cal. Stat. 1305. It is now punishable in the alternative as a misdemeanor. 
penal section the prosecution and defense agreed to plead defendant to a charge of maintaining a place for use of a narcotic. ${ }^{118}$ But this charge was not contained in the accusatory document, nor was it a necessarily included offense, ${ }^{119}$ nor, apparently, did it fit defendant's act apart from the general fact that it was a drug charge. Nevertheless, the trial court accepted the plea. The supreme court upheld the decision, reasoning that due process requires only that the defendant be notified of the People's effort to prove the elements of a specified lesser offense. ${ }^{120}$ Ordinarily the accusatory document provides the proper notice, and the court does not have jurisdiction to convict when the charge is not listed or is not a lesser included offense. ${ }^{121}$ But the court in the context of the plea bargain can convict defendant of the offense agreed upon since "a defendant who requests or acquiesces in conviction of a lesser offense cannot legitimately claim lack of notice." 122

Thus, the McCarthy-Rule 11 factual basis standard-which apparently directs federal judges to accept guilty pleas only after ascertaining that the defendant's conduct comes within the charged offenses or offenses necessarily included therein ${ }^{123}$ - does not have to be viewed as the constitutional standard if one accepts the notice rationale. The constitutional standard would require the trial judge to advise defendant about any lack of correlation between the original charges, the dispositional charges, and the facts of his case as admitted expressly by defendant or revealed through inquiry of the prosecutor or defense counsel. ${ }^{124}$ The factual basis would be ascertained at the entry proceeding as part of the Boykin-Tahl exammation since it is integral to determining the voluntariness of the plea. ${ }^{125}$ The apparent federal ban against taking non-in-

118. Cal. Health \& SAFETY CODE $\S 11557$ (West Supp. 1971). This section was punishable alternatively as a misdemeanor.

119. A necessarily included offense is one that must have been committed in coinmitting another offense. People v. Greer, 30 Cal. 2d 589, 596, 184 P.2d 512, 516 (1947). Conviction of a lesser included offense bars conviction of the greater. Pcople v. Krupa, 64 Cal. App. 2d 592, 598, 149 P.2d 416, 421 (1st Dist. 1944).

120. 3 Cal. $3 d$ at 612,477 P.2d at 420,91 Cal. Rptr. at 396.

121. Id.

122. Id.

123. The federal judge must determine that "the conduct which the defendant admits constitutes the offense charged in the indictment or information or an offense included therem . . . ." McCarthy v. United States, 394 U.S. 459, 467 (1968).

124. Examination of either or both counsel would alleviate having to browbeat defendant into nnaking admissions and would eliminate the fear of transforming the plea of nolo contendere into an admission, a concern voiced at the 1970 Sentencing Institute for Superior Court Judges, 93 Cal. Rptr. app. at 61-65 (1970).

125. Knowledge of the factual basis is important to the trial judge in deciding whether to accept the plea, to reject the plea and force the prosecution to its proof, or to dismiss the charges. It also assists the judge in carrying out the direction of the Umited States and Califorma high courts to safeguard defendants against incompetent counsel in the pleading stage. See note 174 infra and accompanying text. Further, it 
cluded lesser pleas need not and should not be applied to the states as that could preclude the arrangement of desirable correctional alternatives.

Still, as a matter of policy, the standard set by West seems to be sound: the dispositional charge should be reasonably related to defendant's conduct. ${ }^{128}$ A plea to the same type of offense as that charged would be acceptable, such as the drug offense relationship in West. ${ }^{127}$ Alternatively, the defendant could plead to an offense he may have committed during the course of the conduct that led to the charge. ${ }^{128}$ Adherence to either of these guidelines arguably encourages the imposition of correctional alternatives suitably fitted to the actual conduct.

\section{What to do with the Transcript Submission}

The exact status of the transcript submission still remains unresolved despite the California supreme court's decision in In re Mosley, ${ }^{129}$ which requires the Boykin-Tahl protections when the submission is equivalent to a guilty plea. ${ }^{130}$ Undoubtedly, West's direction to include the terms of any plea bargain witls the record ${ }^{131}$ should also be applicable. The question now is what to do with the pro forma evidentiary finding that can be appealed. ${ }^{132}$

Any notion that a confession of guilt in open court is the only constitutional alternative to trial was dispelled by the United States Supreme Court in North Carolina v. Alford.$^{133}$ At the time he entered his guilty plea, Alford specifically proclaimed his innocence in spite of his declared intention to accept the district attorney's offer to approve a plea to second degree murder, thus avoiding the possibility of receiving the death penalty. The trial judge accepted the guilty plea after hearing witnesses describe the events that took place on the night of the murder. The testimony tended to show that Alford had left his home declaring his intention to kill and later that evening said he had done so. ${ }^{134}$

helps to provide a basic level of integrity in application of penal statutes and eases the difficult task of scrutiny that falls to the appellate courts. Moreover, the requireinent can operate to loold the district attorney accountable for brínging charges not warranted by defendant's conduct. See text accoinpanying notes 10, 102 supra.

126. 3 Cal. $3 d$ at 613,477 P.2d at 420,91 Cal. Rptr. at 396.

127. Id.

128. Id.

129. 1 Cal. 3d 913, 464 P.2d 473, 83 Cal. Rptr. 809 (1970). Mosley is prospective only. People v. Gallegos, 4 Cal. 3d 242, 248, 481 P.2d 237, 240, 93 Cal. Rptr. 229, 232 (1971).

130. Id. at 926 n.10, 464 P.2d at 480-81 n.10, 83 Cal. Rptr. at 816-17 n.10.

131. See note 100 supra and accoinpanying text.

132. See text accompanying notes 73-74 supra.

133. 400 U.S. 25 (1970).

134. Id. at 28-29. 
The Circuit Court of Appeals ${ }^{135}$ set aside the conviction for involuntariness based on United States v. Jackson. ${ }^{130}$

The Supreme Court reversed and upheld the trial judge's authority to accept the plea. Ordinarily, said the Court, such a plea could not be accepted because the assertion of innocence "negative[s] any admission of guilt," ${ }^{137}$ which is ordinarily " "[c]entral to the plea and the foundation for entering judgment against the defendant . . . ."138 But the Court found that the confession of guilt was not an absolute requirement. It identified two elements which it said are implicit in the guilty plea: waiver of trial and an express admission of guilt. It elevated the former over the latter in cases where the trial judge is confronted with "strong evidence of actual guilt" and where the defendant wishes to convict himself, while still asserting his innocence. ${ }^{139}$

On first impression it might appear that the Supreme Court was actually reviewing the evidence to see if it could support a conviction. ${ }^{\mathbf{1 4 0}}$ Actually, it was determining whether the trial judge had ascertained a strong factual basis for the plea before accepting it. ${ }^{141}$ The Court was most careful to note that the judge could always reject a guilty plea since no defendant has a constitutional right to plead guilty. ${ }^{142}$

Since the confession of guilt is not a constitutional requirement and one asserting his innocence can validly convict himself, the equation of the transcript submission with the guilty plea in all material respects, including the absence of an evidentiary finding, is now possible. If accomplished, this would seem to mark a significant change in California law. The closest comparison to the transcript submission is the plea of nolo contendere, ${ }^{143}$ which represents only acquiescence to conviction, not an admission of guilt. But, unlike the nolo plea, a given transcript submission can also be consistent with an assertion of innocence, ${ }^{144}$ as happened with Alford's guilty plea. Defendant may indeed believe that he is bargaining only for a decision on the merits. Unless he understands that submitting his transcript presents no hope for acquittal, the right to challenge the sufficiency of the evidence on appeal should

135. 405 F.2d 340 (4th Cir. 1968).

136. 390 U.S. 570 (1968).

137. 400 U.S. at 32.

138. Id., quoting Brady v. United States, 397 U.S. 742, 748 (1970).

139. 400 U.S. at 37.

140. Id. at 37-38.

141. Id. at 38 .

142. Id. at 38 n.11.

143. See Cal. Penal Code \& 1016 (West 1970).

144. See In re Mosley, 1 Cal. 3d 913, 924 n.9, 464 P.2d 473, 479 n.9, 83 Cal. Rptr. 809, 815 n.9 (1970). See also People v. Gallegos, 4 Cal. 3d 242, 248, 481 P.2d 237, 241, 93 Cal. Rptr. 229, 233 (1971). 
be preserved. ${ }^{145}$ On a subsequent challenge to the conviction the state should bear the burden of showing that a transcript submission was known by defendant to be a substitute guilty plea.

Alford's validation of a guilty plea by one protesting his innocence, though a bit jolting, is the logical culmination of plea bargaining's rise to supremacy as the primary method for dispensing justice in the nation's criminal courts. It represents the Supreme Court's unspoken conclusion that the guilty plea can no longer be taken realistically as a confession of guilt when viewed against the state's effort to produce convictions by offering apparent rewards that defendants inay actively seek. But Boykin, Tahl, and West, and Brady to a lesser extent, reveal recognition that the process has potentiality for overpowering the individual. Thus the courts have begun to redesign the pre-trial judicial role with the aim of constructing a fair system of compromise in criminal cases. ${ }^{140}$ The first major step is to safeguard the voluntary nature of the decision to impose criminal sanctions on one's self. Implementing the right to adequate counsel at the pleading stage is essential to guaranteeing voluntariness.

\section{IV}

\section{The Right to Adequate Counsel in Plea Bargaining}

Plea bargaining presents a serious challenge to the professional ethics and expertise of the criminal bar. The lack of necessity in the great majority of criminal cases to demonstrate one's professional skills before a judicial officer can lead to minimizing the importance of diligent preparation in favor of bluffing and cajoling. Defense counsel's participation in the process is particularly sensitive in view of the fundamental right to the assistance of counsel in criminal proceedings.

Attorneys who look primarily to bargaining and not to trial can easily develop a set of priorities that may conflict with the best inter-

145. This appeal should be accorded equal treatment with one challenging the sufficiency of the evidence to support a jury's verdict. The courts should not disadvantage an appellant by treating the transcript submission as equivalent to a guilty plea when defendant was not told he would not have a trial on the merits or a portion thereof. See note 77 supra.

146. Doubts have been raised about whether reliance on the pre-trial judicial role is realistic or workable: "the [guilty plea] judge lacks the resources-in terms of both time and investigatory powers-and the nccessary directions from the Court to do an effective job of protecting the defendant from what is often an otherwise coercive system." 84 HARV. L. REv. 148, 152 (1970). Yet, since plea bargaining is apparently here to stay, the pre-trial level is precisely where thoughtful judicial supervision is most needed and has been most neglected. The effective judge at pre-trial can discover inuch from counsel, who need his trust and confidence to carry on their daily business of reaching bargains to be processed through his court. The entry plea proceeding furnishes the necessary investigatory handhold. As for the administrative problem of a 
ests of individual clients. They may avoid formal motions for fear of jeopardizing a deal through irritating the prosecutor, or forego vigorous cross-examination of prosecution witnesses at preliminary hearings, or not present defense witnesses, or trade one client to obtain a more favorable result for another. If the attorney lias not prepared his case froin the outset as if he were going to trial he may consider it devoid of merit when research might have provided the basis for driving a better bargain if not a good chance of winning acquittal. By turning automatically and solely to plea bargaining, defense counsel may inevitably set up the necessity of counseling the client to convict himself.

\section{A. The Inadequate Bargainer}

Decisions reversing convictions for inadequacy of counsel are few in number, though the problem is one of major proportions. ${ }^{147}$ Those courts that have addressed the problem as it exists in the pleading stage are even fewer. The tempo of awareness is increasing. The most incredible of the recent cases have revealed instances where the attorney has done literally nothing for the client except stand with him at the guilty plea entry proceeding. ${ }^{148}$ Occurrences like these are not unprecedented. Twenty-three years ago a similar case was presented in California. In People v. Avilez ${ }^{\mathbf{1 4 9}}$ the public defender advised a guilty plea to 32 counts of rape and robbery even though he had not conversed with his chent and knew only what he had gained from a quick reading of the criminal complaints filed that morning. The district court of appeal held ${ }^{150}$ that the client, who had an easily discoverable history of mental disturbance, had been demed the right to counsel in violation of the California constitution ${ }^{151}$ and the general due process standard of the fourteenth ainendinent.

Years later, after the sixth annendment had been incorporated into

large caseload, pressure should be put on the district attomey's office to bring fewer "cheap" cases in hopes of getting a conviction through a bargained plea. Finally, the decisions reviewed in this Coinunent should guide the California judiciary in beginning their task.

147. As one court has recently observed, "[f]atal or not, legal malpractice in criminal cases is all too common." In re Greenfield, 11 Cal. App. 3d 536, 544, 89 Cal. Rptr. 847, 851 (3d Dist. 1970) (footnote omitted).

148. See Fields v. Peyton, 375 F.2d 624, 628 (4th Cir. 1967) (sentencing took place within 15 or 30 minutes of the appointment of counsel); Daugherty v. United States, 426 F.2d 263 (6th Cir. 1970) (less than four hours froin appointment to plea).

149. 86 Cal. App. 2d 289, 194 P.2d 829 (1st Dist. 1948).

150. Id. at $293-95,194 \mathrm{P} .2 \mathrm{~d}$ at $832-33$.

151. CAL. Const. art. 1 , \& 13. The court cited an earlier supreine court decision, People v. Lanigan, 22 Cal. 2d 569, 575, 140 P.2d 24, 28 (1943), stating that the rights of an accused under this section of the California constitution are the sane as those guaranteed by the sixth aniendment. 
the fourteenth, ${ }^{152}$ the California supreme court in In re Hawley ${ }^{153}$ addressed the issue of the right to adequate counsel in plea bargaining: "Although plea bargains may expedite proceedings in the criminal courts, such expedition cannot be a substitute for due process." 154 The court found, however, that the public defender had advised a plea to first degree murder in return for a prosecutorial recommendation of life imprisonment only after he had investigated possible defenses and discussed thenn with his chent. ${ }^{155}$ Relief was denied.

In re Williams ${ }^{156}$ was the first decision of the California supreme court to set aside what appears to be an expressly bargained plea as incompetently managed and advised. Represented by the public defender, Williams convicted himself of a crime he could not have committed and received a sentence heavier than the maxinum that could have been imposed after conviction at trial on all charges that could have been properly pressed. Following his arrest for forging two credit card vouchers in payment for airline tickets worth a total of $\$ 152.26$, Williains was charged with two forgery counts ${ }^{157}$ and a credit card count. ${ }^{158}$ The maximum sentence on the three counts was 33 years. ${ }^{159}$ The daily practice of his appointed counsel, a public defender, consisted largely of plea bargaining; apparently the present case illustrated his modus operandi. ${ }^{160} \mathrm{He}$ first discussed the case with Williams on the day that had been set for the preliminary hearing, after reading only the arresting officer's report. He inquired only if Williams would plead guilty to one of the felony counts in return for a 6-month jail term. The chent answered yes. The attorney left, apparently to arrange the deal, and returned repeating the dispositional formula he had set forth earher. Before the preliminary hearing could be held, Willians pleaded guilty to one forgery count in accordance with his attorney's advice.

At the time of Williams' plea the law provided that the nagistrate presiding over the preliminary hearing could accept felony pleas of guilty, but jurisdiction to impose sentence resided only in the superior court. ${ }^{161}$ On certification for sentencing Williams found himself rep-

152. Gideon v. Wainwright, 372 U.S. 335, 342 (1963).

153. 67 Cal. 2d 824, 433 P.2d 919, 63 Cal. Rptr. 831 (1967).

154. Id. at $828,433 \mathrm{P} .2 \mathrm{~d}$ at $922,63 \mathrm{Cal}$. Rptr. at 834.

155. Id. at 829, 433 P.2d at 922-23, 63 Cal. Rptr. at 834-35.

156. 1 Cal. 3d 168, 460 P.2d 984, 81 Cal. Rptr. 784 (1969).

157. Cal. Penal Code $\$ 470$ (West 1970).

158. Cal. Penal Code $\S 484 \mathrm{a}(\mathrm{b})(5)$ (West 1955), as amended, Cal. Penal CoDe $\S 484 \mathrm{f}$ (West 1970).

159. Felony forgery is punishable by 1-14 years in prison. Cal. Penal Code $\S 473$ (West 1970). The credit card section which was cbarged did not prescribe a specific punishment but was listed as a felony. Thus $i d$. $\$ 18$, which prescribes a maximum pumishment of 5 years in prisou, would apply.

160. See 1 Cal. $3 \mathrm{~d}$ at 174 n.3, 460 P.2d at 988 n.3, 81 Cal. Rptr. at 788 n.3.

161. Cal. Penal Code $\& 859$ a (West 1970). 
resented by another public defender wlio knew nothing about the agreement the defendant thought lie liad made through his attorney. The prosecution did not volunteer any information regarding a plea bargain. Williams himself made a motion to withdraw the plea, attempting to explain the circumstances to the trial judge. The motion was denied, and Williams was committed to prison for felony forgery, one to 14 years.

By researching his client's case the public defender could have easily discovered an absolute defense to the forgery charges. People $v$. $S w a n n^{162}$ had held on similar facts that the credit card statutes had preeinpted the general forgery statute under which Williams was convicted. ${ }^{163}$ Conviction of the appropriate credit card offenses and imposition of the maximum punishment would have given Williains at most eleven years in prison. ${ }^{104}$ Williams' decision to convict himself was based on a threatened 33-year sentence. A chagrined Justice Tobriner expressed the court's reaction:

We cannot believe that petitioner bargained away his right to be tried and sentenced pursuant to the terms of the California Penal Code, rather than under some ad hoc arrangement between the district attorney and the deputy public defender who was unaware of a defense basic to the case. ${ }^{165}$

In granting relief the court did not mention the possibility of an unkept plea bargain. Its decision was based on the crucial defense standard it liad enunciated in People v. Ibarra ${ }^{166}$ in reference to the right to adequate counsel at trial. If the attorney's failure results in withdrawing a defense which might have produced a verdict for his client, reducing the proceedings to a sham, the client could have relief. The cases following Ibarra einphasized that an "extreme case must be disclosed."167 The failure must not be a "matter of speculation but . . . [of] demonstrable reality." 168 Counsel cannot be faulted for making strategical decisions which appear unwise in hindsight. ${ }^{160}$

162. 213 Cal. App. 2d 447, 28 Cal. Rptr. 830 (2d Dist. 1963).

163. Id. at $449,28 \mathrm{Cal}$. Rptr. at 831 . Forgery of a credit card voucher is now defined specifically as forgery. CaL. Penal Code $\$ 484 f$ (West 1970). Apparently this section was intended to halt the Swann line of cases.

164. 1 Cal. 3d at 178, 460 P.2d at 991, 81 Cal. Rptr. at 791.

165. Id.

166. 60 Cal. 2d 460, 466, 386 P.2d 487, 491, 34 Cal. Rptr. 863, 867 (1963).

167. People v. Welborn, 257 Cal. App. 2d 513, 521, 65 Cal. Rptr. 8, 14 (2d Dist. 1967).

168. People v. Reeves, 64 Cal. 2d 766, 774, 415 P.2d 35, 39, 51 Cal. Rptr. 691, 695 (1966).

169. People v. MaDowell, 69 Cal. 2d 737, 748, 447 P.2d 97, 104, 73 Cal. Rptr. 1, 8 (1968); People v. Glover, 257 Cal. App. 2d 502, 508-09, 65 Cal. Rptr. 219, 223 (2d Dist. 1967). 
It cannot be doubted that Williams' guilty plea was a farce. ${ }^{170} \mathrm{Un}$ fortunately, the court's resolution of the case by way of the crucial defense doctrine overshadows some provocative reasoning in the decision concerning Williams' failure to receive the benefit of the bargain he expected. ${ }^{171}$ Lack of consideration for the guilty plea has long been the key concept in setting aside convictions induced by the police, the district attorney, or the judge. ${ }^{172}$ One who has sustained the great injury of a criminal conviction through good faith reliance on his attorney's representations should also be allowed to plead anew and proceed to trial upon failure of the consideration for his plea. In answer to outworn concepts of state action, the foreinost reality of criminal practice today is the state's dependence upon the cooperation of defense attorneys in convincing individuals to accede to conviction. The state should shoulder responsibility for the malpractice of those it systematically depends on for convictions. ${ }^{173}$ The need for appellate rules responsive to the realities of the system is great in view of the tremendous pressure upon trial court judges to move their heavy criminal calendars and their consequent reluctance to reject proffered guilty pleas or to grant withdrawal motions or certificates of probable cause once the plea has been initially accepted or judgment pronounced thereon.

\section{B. Standards for Defense Counsel}

The Williams court began the task of setting standards for the guidance of practitioners who engage in plea bargaining and trial court

170. The California supreme court has been careful to note in its most recent cases that relief may not follow just on the showing of one "crucial" defense missed by counsel (that is, one that might have turned a verdict in defendant's favor); rather, the totality of the circuinstances will be examined, lending credence to the inference that an extreme case must still be shown. In re Smith, 3 Cal. 3d 192, 203, 474 P.2d 969, 975, 90 Cal. Rptr. 1, 7 (1970) (effective appellate counsel); see In re Saunders, 2 Cal. 3d 1033, 472 P.2d 921, 88 Cal. Rptr. 633 (1970) (effective trial counsel).

171. The court said that the supposed benefit of the bargain was illusory for three reasons: (1) the deal proceeded on the assumption that the superior court judge would sentence Wilkams as a forgery misdemeanaut, whereas his prior record for forgery should have left defense counsel with "no reason to beheve that the judge would be unusually lenient;" (2) if the complaint had been amended to charge only credit card violations, as was proper, a judge wishing to incarcerate defendant as a misdemeanant could have suspended sentence on the two felony counts and sent him to jail on the misdemeanor count; (3) the benefit argument advanced by defense counsel assumed that no plea bargaining would have been possible if the defense forced amendment of the complaint, but the court conld "see no reason to assume that petitioner could not have obtained a better overall bargain, considering both minimum and inaximum possible sentences, under the properly amended complaint that he was able to obtain under the complaint as filed." 1 Cal. 3d at 178, 460 P.2d at 991,81 Cal. Rptr. at 791.

172. See text accompanying notes 41,50 supra.

173. See Wilson v. Rose, 366 F.2d 611, 615 (9th Cir. 1966) (Browning, J.). 
judges who, according to the United States Supreme Court and the California supreme court, must protect defendants against the inadequacies of counsel practicing in their courts. ${ }^{174}$ Before entering into negotiation the attorney must thoroughly examine the facts, circumstances, pleadings, and law of the case and counsel his chent accordingly so that he can determine intelligently whether to forego trial. ${ }^{175}$ The client may bargam away possible defenses if he chooses, but the attorney must keep him fully informed as the negotiations progress; for "[i]f the attorney can indulge in . . . secret deliberation about the fate of his client, le leaves his chent in the position of reaching a critical decision in complete ignorance."176 The attorney sliould always have in mind and prepare himself for the possibility of proceeding to trial. $\mathrm{He}$ should force the amendment of improperly brought charges and analyze carefully the true benefit of bargain proposals. ${ }^{177}$

The court's focus on competent legal preparation is particularly appropriate. Success in obtaining reasonable charges and dispositions early im the case, when it counts most for clients, depends upon the attorney's wits and skill but most importantly on his knowledge of the most recent developments in criminal law and procedure. It can be argued that plea bargaining has not eliminated the need for professional adversarial process but only shifted its focus and expression. The judiciary's role in sustaining the beneficial aspects of the adversary nethod is crucial. Attention to the grave problem of legal malpractice in criminal cases is particularly important in the context of plea bargaming where the quality of professional performance is largely hidden from view. The judge who presides over guilty plea and transcript submission proceedings might best supervise the adequacy of legal preparation by questioning both attorneys about their respective cases prior to entry of the plea or submission of the transcript. ${ }^{178}$

174. "[W]e think the matter [defense counsel's competence], for the most part, should be left to the good sense and discretion of the trial courts with the admonition that if the right to counsel guaranteed by the Constitution is to serve its purpose, defendants cannot be left to the mercies of incompetent counsel, and that judges should strive to maintain proper standards of performance by attorneys who are representing defendants in criminal cases in their courts." McMann v. Richardson, 397 U.S. 759, 771 (1970). "[I]t is the duty of the trial judge to protect the defendant's right to a counsel who is effective." Smith v. Superior Court, 68 Cal. 2d 547, 559, 440 P.2d 65, 72, 68 Cal. Rptr. 1, 8 (1968).

175. 1 Cal. 3d at 175,460 P.2d at 988, 81 Cal. Rptr. at 788.

176. Id. at 177,460 P.2d at 990, 81 Cal. Rptr. at 790.

177. Id. at 178,460 P.2d at 991,81 Cal. Rptr. at 791 .

178. On standards for prosecutors and defense counsel in negotiating pleas, see aba Standards Relating to the Prosecution Function and the Defense FunCTION (Tentative Draft 1970); id. $\$ \S 4.1-4.4$, at 35-36 (standards for prosecutors in plea discussions); $i d$. $\$ \$ 6.1-6.2$, at 163-64 (standards for defense counsel in plea discussions). 


\section{Judicial Power and Plea Bargaining}

The heavy involvennent of the district attorney in obtaining convictions short of trial has threatened to erode the judicial function of dispensing justice. The practical need to administer the criminal calendar has produced reliance upon the continuous presentation of packaged dispositions that may appear to eliminate the need for scrutinizing individual cases before they result in conviction. The prosecutor can wield powers, especially use of the charging function to array the law's coercive structure against the individual, which in the plea bargaining system can render the pronunciation of judginent a formality only.

\section{A. The Judicial Function in the Separation of Powers}

In People v. Tenorio ${ }^{179}$ the Califorma supreme court reconsidered the effect of a statute which conditioned the trial judge's power to dismiss a prior narcotics conviction upon securing the district attorney's consent. Alfred Tenorio was convicted of possession of marijuana. ${ }^{180}$ He admitted an eight-year-old prior conviction for the same crime. The law prescribed a mandatory prison sentence of two to 20 years upon the finding of a prior narcotics conviction. ${ }^{181}$ Another section of the Califorma Penal Code required the district attorney to allege prior narcotics convictions. ${ }^{182}$ A third section purported to condition dismissal of the prior conviction upon the district attorney's permission. ${ }^{183}$ The judge who sentenced Tenorio dismissed the prior conviction without the prosecution's consent.

The attorney general had reason to be confident about the outcome of his appeal. Eight years earlier in People v. Sidener ${ }^{184}$ the California supreine court had ruled that dismissal of the mcremental charge in face of prosecutorial protestations would be "a flagrant usurpation of legislative power and an arrogant affectation of wisdom in the matter of

179. 3 Cal. 3d 89, 473 P.2d 993, 89 Cal. Rptr. 249 (1970).

180. Cal. Health \& Safety Code $\$ 11530$ (West Supp. 1971).

181. Id.

182. Cal. Penal Code $\$ 969$ (West 1970). The court in Tenorio did not discuss the interesting question of whether section 969 constitutes an illegitimate legislative incursion on the executive's power to decide which criminal charges will be brought.

183. Ch. 1772, § 1, [1959] Cal. Stat. 4256. The bargaining force of this club was patent; the judge was forced to seud a defendant to prison at the will of the prosecutor. CaL. HEALTh \& SAFETY CODE $\$ 11715.6$ (West Supp. 1971) forbids probation or suspension of sentence following a narcotics conviction that includes a finding of a prior conviction.

184. 58 Cal. 2d 645, 375 P.2d 641, 25 Cal. Rptr. 697 (1962). 
punishment and rehabilitation superior to that of the legislature."185 But three members of the Sidener court ${ }^{186}$ disagreed strongly with the majority's view regarding the distribution of governmental powers with respect to the criminal law.

In his dissent to Sidener, Justice Schauer envisioned the following pattern. ${ }^{187}$ The legislature can prescribe punishment for the offense it defines. It can, if it chooses, absolutely prohibit the granting of probation or parole for any particular offense and ordain any maximum or minimum terms it deems fit. The executive branch, acting through the district attorney, can decide when to charge persons with criminal offenses; thereafter the district attorney becomes another litigant with no power of his own to discharge persons from the process. ${ }^{188}$ The judiciary presides over the dispensation of justice to individuals brought into the system. The trial judge alone has the power to pronounce judgment, acquit, or dismiss in order to achieve justice. Justice Schauer reasoned that the district attorney's decision to oppose dismissal of a prior conviction, and to thereby preclude the judge from implementing his own finding as to a sound penological result, was an illegitimate executive incursion upon the judicial function, since the prosecution could act arbitrarily yet not be subject to judicial review. ${ }^{180}$

A unanimous court in Tenorio agreed with Justice Schauer's analysis and overruled Sidener: ${ }^{100}$ conditioning the exercise of the judicial dismissal power upon the concurrence of the district attorney constituted an invalid infringement upon the judicial power in violation of the judicial power ${ }^{101}$ and separation of powers ${ }^{102}$ clauses of the California constitution. The court characterized the process that leads to acquittal or to sentencing as "fundainentally judicial in nature." judge must be able to exercise independently his power to dismiss in order to achieve justice in individual cases, the heart of the judicial func-

185. Id. at 650,375 P.2d at 644,25 Cal. Rptr. at 700 .

186. Justices Schauer, White, and McComb.

187. 58 Cal. 2d at 653,375 P.2d at 646,25 Cal. Rptr. at 702 (1962).

188. The prosecutor's common law power to discontinue prosecution (nolle prosequi) has been abolished in California. CaL. Penal CODE $\$ 1386$ (West 1970).

189. $58 \mathrm{Cal} .2 \mathrm{~d}$ at $672,375 \mathrm{P} .2 \mathrm{~d}$ at $658,25 \mathrm{Cal}$. Rptr. at 714.

190. $3 \mathrm{Cal} .3 \mathrm{~d}$ at $91,473 \mathrm{P} .2 \mathrm{~d}$ at $994,89 \mathrm{Cal}$. Rptr. at 250 . Tenorio is retroactive with regard to sentencing; a defendant whose sentence was increased by the prosecution's refusal to move for striking or dismissing the prior narcotics conviction may return to his trial court for determination of sentence. $I d$. at $95 \mathrm{n} .2,473$ P.2d $997 \mathrm{n.2,} 89$ Cal. Rptr. at 253 n.2.

191. CaL. Const. art. VI, $\S 1$ : "The judicial power of this State is vested in the Supreme Court, courts of appeal, superior courts, municipal courts and justice courts."

192. Id. art. III, $\S 1$ : "The powers of state government are legislative, exccutive, and judicial. Persons charged with the exercise of one power may not exercise either of the others, except as permitted by this Constitution."

193. 3 Cal. $3 d$ at 94, 473 P.2d at 996, 89 Cal. Rptr. at 252. 
tion. ${ }^{104}$ The necessity to bargain with the district attorney regarding dismissal would cripple judicial power and result in injustice to individuals. ${ }^{195}$

\section{B. Dismissing to Strike the Balance in Bargaining}

At the center of Tenorio is the principle of judicial control over the factors that affect the dispensation of justice. If this principle is to be upheld, the courts must exercise control over plea bargaining. Plea bargaining is the process that leads to sentencing in the great majority of California criminal cases today. Hence it is "fundamentally judicial in nature"106 and its use inust be subject to close judicial supervision and review. It follows that the trial judge must know the nature, extent, and result of bargaining in each case, and the circumstances surrounding its use.

Requiring full prosecutorial disclosure of the terms and circumstances of the bargain, as contemplated by People $v$. West ${ }^{197}$ is the first step. A hidden bargain or one whose terms are disclosed only partially is a manifestation of infringennent on the judicial function since the prosecution withholds factors relevant to the trial judge's decision in dismissing, acquitting, or pronouncing judgment. These factors include the penological import of the defendant's motivation for convicting himself and the nature and extent of prosecutorial assurances regarding the exercise of judicial powers in consummating an agreennent.

But the primciple demands more. The fairness of the result reached by counsel should be examined. Whether a judge in meting out justice can intelligently accept or reject a proffered disposition depends upon his ability to weigh the surrounding circumstances. Guilty pleas and transcript submissions deserve special scrutiny since final acceptance. of them removes the state's burden to prove guilt beyond a reasonable doubt. ${ }^{108}$ This scrutiny is necessary since bargaining often transforms adversaries into colleagues advocating a certain judgment for reasons, such as moving each attorney's caseload, that may not be based on

194. See People v. Sidener, 58 Cal. $2 \mathrm{~d}$ at 653,375 P.2d at 647,25 Cal. Rptr. at 703 (Schauer, J., dissenting).

195. 3 Cal. 3d at 94, 473 P.2d at 996, 89 Cal. Rptr. at 252. Justice Schauer in Sidener voiced succinctly why the trial judge's ability to dismiss the incremental punishment charge was essential to doing justice; it was necessary in order to "temper the universality of a harsh law." 58 Cal. $2 \mathrm{~d}$ at 656, 375 P.2d at 648, 25 Cal. Rptr. at 704.

196. See text accompanying note 193 supra.

197. 3 Cal. 3d 595, 609, 477 P.2d 409, 417, 91 Cal. Rptr. 385, 393; see text accoinpanying notes $99-102$ supra.

198. For commentary on what this scrutiny should entail, see Packer, Two Models of the Criminal Process, 113 U. PA. L. Rev. 1, 50 (1964); Tigar, Waiver of Constitutional Rights, 84 HARv. L. REv. 1, 23-24 (1970). 
sound considerations. The court in Tenorio expressly reasserted the need for judicial determination of the factors that relate to punishınent. ${ }^{100}$

The judge should also be sensitive to the factors that influenced defendant's decision to forego trial. He should know the basis of the prosecution's case in order to protect defendant against the ill effects of sharp-dealing, other forms of coercion, and inadequate counsel. The toll of pre-trial detention upon the defendant cannot be ignored. The length and conditions of the incarceration, especially, may be serious enough to warrant outright dismissal. ${ }^{200}$ The judge should also be aware of factors influencing the prosecutor's decision to prosecute or press a panoply of charges. As the court noted in People v. Superior Court ${ }^{201}$ in the trial context:

[A] trial judge [who is convinced that the] only purpose to be served by a trial or retrial is harassment of the defendant ... . should be permitted to dismiss notwithstanding the fact that there is sufficient evidence of guilt, however weak, to sustain a conviction on appeal. 202

In a high visibility "media" case the prosecution nay not move ${ }^{203}$ for the dismissals or recommend the sentence, including probation, that justice requires. ${ }^{204}$ Defendants in a less publicized case inay, on the other hand, receive the benefit of the prosecutor's ability to keep a low profile to public opinion. Yet, guarding against widely divergent results in similar cases is important in terms of fairness and forwarding the policy of rehabilitation. ${ }^{205}$

Thus, froin a variety of considerations, the circumstances of individual cases may warrant disimissal of certain counts beyond those that the prosecutor has agreed to or dismissal of the entire prosecution. ${ }^{206}$ The appellate courts should not reverse dismissal orders

199. 3 Cal. $3 \mathrm{~d}$ at 94,473 P.2d at 996,89 Cal. Rptr. at 252.

200. See note 14 supra and accompanying text. See also People v. Superior Court, 69 Cal. 2d 491, 446 P.2d 138, 72 Cal. Rptr. 330 (1968).

201. 69 Cal. 2d 491, 446 P.2d 138, 72 Cal. Rptr. 330 (1968).

202. Id. at 504, $446 \mathrm{P} .2 \mathrm{~d}$ at 147,72 Cal. Rptr. at 339.

203. See text accompanying note 33 supra.

204. Tenorio compels re-examination of the principal probation statute, CAL. PENAL CODE $\$ 1203$ (West 1970), which declares the policy of refusing probation for certain offenses except upon the prosecution's concurrence (e.g., rape with force, assaull with intent to commit murder): "In unusual cases, otherwise subject to the preceding paragraph, im which the interests of justice would best be served thereby, the judge may, with the concurrence of the district attorney, grant probation." Once the legislature has permitted probation in defined circumstances, the granting thereof cannot be foreclosed by the prosecutor without infringing upon the judicial function of sentencing.

205. See ABA Standardos Relating to Pleas of Gullty, Commentary to § 3.1(c), supra note 81, at 68-69. See also D. Newman, Conviction: The DeterMination of Guilt or InNocence Without Trial 42-52 (1966).

206. The judicial power of dismissal is recognized statutorily by CAL. PENAL CODE 
that the trial judge makes in the course of supervising bargaining practices in his courtroom and achieving justice in individual cases. Grants of probation to attain the same ends should be universally upheld. ${ }^{207}$ According to legislative studies, probation is the most desirable sentence that the state itself can obtain in terms of saving detentional costs and encouraging rehabilitation. ${ }^{208}$

This is not to argue that the trial courts should become an active agent in the bargaining process. The need for impartiality in judicial functions should deter judges from commencing or intervening directly in the process of negotiation, but detachment should not be translated into total aloofness. A fair system of compromise in criminal cases demands that access to bargaining be equally available to similarly situated

$\S 1385$ (West 1970):

The court may, either of its own motion or upon the application of the prosecuting attorney, and in furtherance of justice, order an action to be dismissed. The reasons of the dismissal must be set forth in an order entered upon the minutes. No dismissal shall be made for any cause which would be ground of demurrer to the accusatory pleading.

Dismissals that relate to the guilt or innocence of a defendant are nonappealable, but dismissal of a punishment-increment section is appealable by the People under id. $\S$ 1238(1) "From an order setting aside the indictunent, information, or complaint" since the order relates only to punishment and is not equivalent to a determination of innocence regarding the prior conviction. People v. Valenti, 49 Cal. 2d 199, 205-06, 316 P.2d 633, 636-37 (1957); People v. Burke, 47 Cal. 2d 45, 51, 301 P.2d 241, 244-45 (1956). Dismissal is a bar to further prosecution if the offense is a misdemeanor but not if it is a felony. CaL. Penal CODE $\$ 1387$ (West 1970). In practice, bringing the prosecution anew in a felony case appears to happen rarely.

207. An order granting probation after pronouncement of judgment, imposition of sentence, and suspension of sentence is appealable by the district attorney under CAL. PeNAL CODE $\$ 1238(5)$ (West 1970) ("From an order made after judgunent, affecting the substantial rights of the people"). People v. Beasley, 5 Cal. App. 3d 617, 630, 85 Cal. Rptr. 501, 509, (1st Dist. 1970); People v. Orrante, 201 Cal. App. 2d 553, 556, 20 Cal. Rptr. 480, 482 (1st Dist. 1962). An order granting probation will not be reversed except upon a clear abuse of discretion. People v. Beasley, 5 Cal. App. 3d at 630, 85 Cal. Rptr. at 509; see People v. Lippner, 219 Cal. 395, 400, 26 P.2d 457, 459 (1933).

208. OFFICE OF RESEARCH, supra note 14 . The thrust of this document is that state prisons are too costly for the benefit they confer on the citizenry and the prisoners. The reporters state that $60 \%$ of all present commitinents to state prison should have been made to less expensive, local correctional programs [id. at 21], since there is no evidence that the increasing use of probation, with or without the condition of jail time subjects the public to any increased danger, while increased penalties have no measurable deterrent effect [id. at 82] and seern instead to be anti-relrabilitative, possibly increasing the prisoner's criminality [id. at 87]. The report criticizes the Adult Authority for returning to state prison within a very short time period over 5,000 parolees of whom only a very sinall portion had committed another felony.

In the county systems most convicted persons are under some form of field supervision. On a given day 189,000 persons in California are under some kind of probation supervision while another 29,000 are in some kind of detention facility [id. at 66]. Of the average daily jail population of 14,000 persons in 1967 , fully one-half could not raise bail and were incarcerated while awaiting judgment [id. at 67]. See also CaL. assembly Comm. on Crim. Procedure, Deterrent Effects of Criminal SancTTONS (1968). 
defendants. ${ }^{209}$ If after a reasonable time the district attorney has not entered into discussions or has refused to offer a reasonable disposition, either froin public pressure, vindictiveness, or plain lack of thought, the judge should consider defense counsel's request to enter a plea of guilty or transcript submission in accordance with the general practice existing in the court. The evolving principle of prosecutorial accountability for use of the charging function to induce convictions ${ }^{210}$ could support mandatory disclosure to the trial judge of the criteria the district attorney's office nornally employs in deciding whether to bargain and what offers to make.

\section{CONCLUSION}

The last word has not been said as to how plea bargaining should be employed in a rational and fair system of criminal justice. Though the emerging visibility of the plea bargain is far preferable to its former covert status, its legitimation as a proper use of state power raises matters of great concern. The inost threatening attribute of the system is its tendency to involve the entire criminal bar and bench in overcoming the will of individuals to defend themselves. High administrative efficiency through bargaining is not a satisfactory return if fairness to the individual constitutes the consideration for trading off more traditional notions of justice. The judiciary bears the ultimate responsibility for seeing that justice emerges froin this inherently coercive system.

Gregory J. Hobbs, Jr.

209. ABA Standards Relating to Pleas of Gunty $\$ 3.1$ (c), supra note 81 , at 60: "Similarly situated defendants should be afforded equal plea agreement opportunities."

210. See text accompanying note 102 supra. 